\title{
A new occurrence of the Early Jurassic brachiopod Anarhynchia from the Canadian Cordillera confirms its membership in chemosynthesis-based ecosystems
}

\begin{tabular}{|c|c|}
\hline Journal: & Canadian Journal of Earth Sciences \\
\hline Manuscript ID & cjes-2017-0179.R1 \\
\hline Manuscript Type: & Article \\
\hline Date Submitted by the Author: & 28-Sep-2017 \\
\hline Complete List of Authors: & $\begin{array}{l}\text { Palfy, Jozsef; Eötvös Loránd University, Department of Geology; MTA-MTM- } \\
\text { ELTE Research Group for Paleontology, } \\
\text { Kovács, Zsófia; University of Graz, Institute for Earth Sciences (Geology } \\
\text { and Palaeontology); MTA-MTM-ELTE Research Group for Paleontology, } \\
\text { Price, Gregory; Plymouth University, School of Geography, Earth \& } \\
\text { Environmental Sciences } \\
\text { Vörös, Attila; MTA-MTM-ELTE Research Group for Paleontology, } \\
\text { Johannson , Gary; Coastal Geological Consulting Ltd. }\end{array}$ \\
\hline $\begin{array}{r}\text { Is the invited manuscript for } \\
\text { consideration in a Special } \\
\text { Issue? : }\end{array}$ & N/A \\
\hline Keyword: & $\begin{array}{l}\text { cold seep, carbonate petrography, stable isotope geochemistry, dimerelloid } \\
\text { rhynchonellide }\end{array}$ \\
\hline
\end{tabular}




\section{A new occurrence of the Early Jurassic brachiopod Anarhynchia from the Canadian} Cordillera confirms its membership in chemosynthesis-based ecosystems

József Pálfy, Zsófia Kovács, Gregory D. Price, Attila Vörös, and Gary G. Johannson

József Pálfy [palfy@elte.hu], Department of Geology, Eötvös Loránd University, Pázmány Péter sétány 1/C, Budapest, H-1117 Hungary and MTA-MTM-ELTE Research Group for Paleontology, POB 137, Budapest, H-1431 Hungary

Zsófia Kovács [zsofia.kovacs@uni-graz.at] Institute of Earth Sciences, University of Graz, Austria and MTA-MTM-ELTE Research Group for Paleontology, Budapest, Hungary

Gregory D. Price [g.price@plymouth.ac.uk], School of Geography, Earth \& Environmental Sciences, Plymouth University, Drake Circus, Plymouth, PL4 8AA, United Kingdom

Attila Vörös [voros@nhmus.hu] MTA-MTM-ELTE Research Group for Paleontology, POB 137, Budapest, H-1431 Hungary

Gary G. Johannson [coastgeocon@telus.net], Coastal Geological Consulting Ltd., RR1, Van Anda, B.C., V0N 3K0, Canada

Corresponding author: József Pálfy [Email: palfy@elte.hu; Phone: +36 1372-2500 /ext. 8728;

Fax: +36 1381-2130] 
Abstract: Cold seeps, where seepage of hydrocarbon-rich fluids occurs in the sea floor, are sites which harbor highly specialized ecosystems associated with distinctive carbonate sediments. Although their Mesozoic record is scarce and patchy, it commonly includes dimerelloid rhynchonellide brachiopods. Here we report a monospecific assemblage of Anarhynchia from a limestone boulder of Early Pliensbachian (Early Jurassic) age in the Inklin Formation of the Whitehorse Trough in the Stikine terrane, from a locality at Atlin Lake in northern British Columbia. Specimens are among the largest known Mesozoic brachiopods, up to $9 \mathrm{~cm}$ in length, and described here as Anarhynchia smithi n. sp. Early precipitated carbonate cement phases of the limestone have carbon isotopic composition highly depleted in ${ }^{13} \mathrm{C}$, indicative of the influence of microbial oxidation of methane derived from a cold seep. Carbonate petrography of the banded-fibrous cement and other characteristic components supports this paleoenvironmental inference. Volcanogenic detrital grains in the matrix are indistinguishable from those in the sandstone layers in the siliciclastic sequence, suggesting that the seep carbonate is broadly coeval with the enclosing conglomerate. The new record extends the geographic range and species-level diversity of the genus, but supports its endemism to the East Pacific and membership in chemosynthesisbased ecosystems. The distribution of three distinct but congeneric species suggests that allopatric speciation occurred at separate sites along the active margin of western North America, and Anarhynchia was restricted to seep and vent habitats in the Early Jurassic. 


\section{Introduction}

Cold seeps are sites where seepage of methane and/or other hydrocarbon-rich fluids and hydrogen-sulfide emanates from the sea floor. Their geological record contains fossils representative of highly specialized ecosystems associated with distinctive carbonate sediments (Flügel 2010; Kiel 2010a; Joseph 2013). Their record is scarce and patchy, yet it provides crucial clues to reconstruct the evolution of several unrelated groups which were adapted to this peculiar environment and constitute the members of their chemosynthesisbased communities. The fossil biota of cold seeps consists of sedentary benthic organisms, mostly mollusks, tube worms and brachiopods (Campbell 2006; Kiel 2010a,b). Their hallmarks typically include brachiopods of unusually large size of individuals and mono- or oligospecific composition of assemblages (Sandy 2010). The unusual depositional setting is also indicated by the enclosing sediment, often dominated by fluid seepage-derived material such as authigenic carbonate and/or sulfide minerals (Flügel 2010).

The membership of skeletonized metazoans in cold seep-related biotas varies throughout the Phanerozoic. Brachiopods form the most common group in the Late Paleozoic-Early Cretaceous cold seep assemblages (Campbell and Bottjer 1995), exclusively containing members of the rhynchonellide superfamily Dimerelloidea (Sandy 2010).

In this study we report a monospecific brachiopod occurrence from a boulder-sized limestone clast found in the Atlin Lake area, British Columbia. The unusual mode of appearance together with the surprisingly large size of the brachiopods raised suspicion about the peculiarity of the fossils. The original identification of the fossils as Halorella is now corrected, as serial sections help assign them to the genus Anarhynchia. Morphological differences from previously described forms warrant the introduction of a new species. The aim of paleoecological analysis from the new occurrence of this genus, complemented with results of carbonate petrography and stable isotope geochemistry, is to provide independent 
lines of evidence to assess its cold seep affinity. We contribute to the debate whether the genus is an obligate or facultative, opportunistic member of chemosynthesis-based communities. Cold seeps preferentially occur at tectonically active margins, and western North America preserves a long geological history of a convergent margin. However, Mesozoic cold seep occurrences have so far only been known from California and Oregon, but not from the Canadian Cordillera, hence our new record from northern British Columbia helps fill a gap. Given that the record of cold seep biota is inherently patchy both spatially and temporally, each new occurrence is significant for the growing database of these peculiar fossil assemblages and provides new insights to the mode of adaptation, community structure, and evolutionary relationships of seep dwellers (Kiel et al. 2014).

\section{Geological setting}

The fossil locality which yielded the brachiopods reported here lies on the eastern shore of Copper Island within Atlin Lake (Fig. 1) in northwestern British Columbia, Canada. Copper Island is located in the southern part of the lake, which is the largest natural lake in the province, with its northern tip extending into the Yukon Territory.

Bedrock geology of this part of the Atlin Lake area is characteristic of the northern segment of the Whitehorse Trough, an elongated early Mesozoic marine sedimentary basin. The NW-SE trending Whitehorse Trough is regarded as an arc-marginal depocenter next to the east-facing Stikine magmatic arc comprising the Upper Triassic Stuhini Group and the Lower to Middle Jurassic Hazelton Group or the broadly coeval, stratigraphically equivalent Laberge Group to the north, which together form a major component of the Stikine terrane, the largest tectonostratigraphic terrane in the Canadian Cordillera (Monger and Price 2002) (Fig. 1A). The Whitehorse Trough was affected by shortening and tectonic imbrication as a thrust and fold belt developed during the accretionary history of the Cordilleran orogen. 
Southwest-vergent thrusts of mid-Jurassic age include the King Salmon Fault to the west and the Nahlin Fault to the east of the fossil locality; the latter represents the terrane boundary juxtaposing volcanosedimentary arc assemblages of Stikine terrane to oceanic assemblages of the Cache Creek terrane (Monger et al. 1991) (Fig. 1B).

Stratigraphy of the northern Whitehorse Trough is dominated by the Lower to Middle Jurassic (Sinemurian to Aalenian) siliciclastic sequences of the Laberge Group (English et al. 2005). Transport of arc-derived sediment from the west resulted in deposition of coarsergrained conglomerates (Takwahoni Formation) in proximal settings and generally finergrained rocks of the Inklin Formation in more distal setting in the forearc basin characterized by coalescing submarine fan systems (Johannson et al. 1997). The brachiopods were found in the Inklin Formation, which is faulted against Upper Triassic rocks on Copper Island and the southern Atlin Lake area, where the proximal facies is tectonically missing (Wight et al. 2004). The Inklin Formation here is Sinemurian to Late Pliensbachian in age and may reach up to $3500-4000 \mathrm{~m}$ in thickness (Johannson et al. 1997). The brachiopods occur in a bouldersized clast at GSC locality No. C-203329 (UTM grid coordinates: 560350 E, 6572875 N; NTS 1:50 000 map sheet 104N/05), where associated fine-grained layers yielded Metaderoceras cf. evolutum, an ammonoid indicative of the Lower Pliensbachian Imlayi and Whiteavesi zones (Johannson et al. 1997) of the North American regional biostratigraphic scheme (Smith et al. 1988).

The Lower Pliensbachian part of the Inklin Fm. is up to 1500-2000 m thick, conglomerate interbeds are volumetrically minor and contain mostly volcanic clasts, recording rapid basin subsidence and coeval growth of the volcanic arc (Johannson et al. 1997). At the brachiopod locality, pebble counts reveal a subordinate siliciclastic sedimentary component ( $8 \%)$ and extremely rare limestone clasts which represent only $1 \%$ of the total. Johannson et al. (1997) suggest an intraformational origin of the siliciclastic sedimentary 
clasts, in sharp contrast to the underlying Sinemurian conglomerate beds which contain abundant clasts of the Upper Triassic Sinwa Limestone Formation. Johannson (1994) not only noted the rarity of limestone clasts, but also comments on the peculiar fossil content of the dark grey skeletal rudstone embedded in a conglomerate layer. Detailed geological mapping confirmed the predominance of finer-grained lithologies, mostly sandstone and siltstone within the Inklin Formation exposed on Copper Island (Wight et al. 2004; Fig. 1C). The depositional setting there comprises predominantly mid-fan facies with relatively minor lower fan to fan-fringe deposits. The conglomerate unit is unusual for its atypical thickness and coarse clast size for the Inklin succession at Atlin Lake, particularly for Lower Pliensbachian conglomerate there, which is strongly dominated by pebble-grade conglomerate (Johannson 1994). The unit comprises a $21 \mathrm{~m}$ thick layer of inverse to normally-graded pebble-cobble conglomerate with a modal clast size of $8.4 \mathrm{~cm}$ and an average maximum clast size of 29.6 cm: boulders were a minor component and typically small, rarely exceeding $35 \mathrm{~cm}$ (Fig. 2). The brachiopod-bearing boulder was among the largest of the conglomerate boulders with approximate dimensions of $35 \times 25 \times 20 \mathrm{~cm}$ (Fig. 3), and was the only carbonate lithology present. The same degree of rounding and sphericity is not evident in this limestone boulder when compared with the typical coarse conglomerate clasts (Figs. 2B and 3A) and suggests a markedly different and shorter transport history, in view of its relative lack of hardness and greater susceptibility to mechanical abrasion.

Apart from fossil evidence, the age of the brachiopod boulder can also be constrained by its constituent detrital grain component, which is representative of the modal mineralogy of coeval sandstone. The detrital grains are of tuffaceous character; the prevalence of angular broken and whole feldspar crystals that predominantly consist of plagioclase, a lithic clast mode comprised almost entirely of volcanic lithologies, and a high feldspar to quartz ratio with minor, mainly volcanic quartz are all features that illustrate a volcanic provenance (Fig. 
S1). These textural and compositional properties fit closely with petrofacies criteria for Lower Pliensbachian sandstone in the study area, where it is defined by its distinct volcanogenic character (Johannson et al. 1997).

The here studied brachiopod assemblage originates from an active margin setting, from a forearc basin controlled by tectonic activity in the vicinity of a subduction zone. Although tectonic models differ in reconstructing either an intra-oceanic arc (Sigloch and Mihalynuk 2013), accretionary ribbon continent (Johnston 2008) or an arc flanking a marginal sea in proximity of ancient North America (Colpron et al. 2007), they all provide for deep marine environments prone to either hydrothermal fluids or cold seeps emanating from synsedimentary faults.

\section{Material and methods}

The brachiopods were collected in 1992 by one of the authors (GGJ) during his field work for an MSc thesis project. The sample originates from a large boulder-sized limestone clast, distinguished by its fossil content. Johannson (1994) noted that "this dark grey skeletal rudstone represents an in situ accumulation of monospecific brachiopods of unusually large size. A range of juvenile through mature forms is found in this close-packed brachiopod 'paleonest' with some specimens attaining long dimensions in excess of $10 \mathrm{~cm}-\mathrm{a}$ size that is unusually large for brachiopods". In this thesis and subsequent paper (Johannson et al. 1997) the brachiopod was identified as Halorella sp., following a suggestion of the first author of the present study. The identification, proved erroneous here, was prompted by external similarity to this well-known Late Triassic brachiopod genus, and the possibility of the limestone clast deriving from the Upper Triassic Sinwa Formation.

Because the uniqueness of the fossil find, unusual mode of occurrence and large size defied simple explanation, all collected material was subjected to further paleontological, 
161 sedimentological and geochemical study. The available material includes 11 brachiopod

162 specimens. All are well-preserved, mostly articulated valves of shelly specimens, although

163 some are fragmentary. Transverse serial sections for studying the internal morphology were

164 made using standard techniques (Sandy 1986). Photographed specimens were coated with

165 ammonium chloride.

166 Thin sections for carbonate petrography were studied using a Nikon Labophot2-Pol

167 optical microscope. Selected thin sections were partially stained with a mixture of potassium

168 ferricyanide and alizarin red dissolved in $\mathrm{HCl}$.

169 Carbonate samples were analyzed at Plymouth University for carbon and oxygen stable

170 isotopes. Using 200 to $300 \mu \mathrm{g}$ of carbonate, stable isotope data were generated on a VG

171 Optima mass spectrometer with a Gilson autosampler. Isotope ratios were calibrated using

172 NBS19 standards and are given in $\delta$ notation relative to the Vienna Pee Dee Belemnite

173 (VPDB). Reproducibility was generally better than $0.1 \%$ for samples and standard materials.

174 Subsamples taken for trace element analysis were digested in $\mathrm{HNO}_{3}$ and analysed by

175 Inductively Coupled Plasma-Atomic Emission Spectrometer (ICP-AES) using a PerkinElmer

$176 \quad 3100$ at Plymouth University. Based upon analysis of duplicate samples reproducibility was

177 better than $\pm 3 \%$ of the measured concentration of each element. Repeat analyses of standards

178 JLS-1 and BCS CRM 393 was within 2\% of the certified values for Sr, Mn, Ca and Mg and

$179 \quad 10 \%$ for Fe. 


\section{Results}

181

182

Systematic paleontology (by J. Pálfy and A. Vörös)

The studied material is deposited with the National Invertebrate and Plant Type Fossil Collection in Ottawa, Ontario. The classification of Manceñido and Owen (2001) and Williams et al. (2002) is followed here.

Phylum Brachiopoda Dumeril 1806

Subphylum Rhynchonelliformea Williams et al. 1996

Class Rhynchonellata Williams et al. 1996

Order Rhynconellida Kuhn 1949

Superfamily Dimerelloidea Buckman 1918

Family Peregrinellidae Ager 1965

Subfamily Pergrinelloideinae Dagys 1968

Genus Anarhynchia Ager 1968

Remarks: The genus was introduced when its type species, Anarhynchia gabbi was first described by Ager (1968). An externally similar rhynchonellid genus, Peregrinelloidea was erected in the same year by Dagys (1968) and it was subsequently suggested that they may be synonyms with the latter name having priority (Manceñido and Dagys 1992). However, further studies of the internal structure of $A$. gabbi and its comparison with serial sections of the Siberian forms clearly establish differences in their crura which warrant retaining them as separate genera (Sandy 2001). 
Anarhynchia smithi n. sp.

Figs. 4.1-7, 5, 6, 7a, b

Diagnosis: Biconvex rhynchonellide of subcircular shell outline and straight commissures, attaining unusually large size for its group. Coarsely ornamented by blunt ribs, some irregularly splitting into secondaries. Ventral valve with massive hinge teeth and no dental plates, dorsal valve with prominent cardinal process and no median septum. Long and ventrally curved, blade-like crura of submergiform to ensiform type.

Types and other material: Holotype - GSC 139295; paratypes - GSC 139294, 139297, 139298; and seven other specimens.

Type locality and horizon: East shore of Copper Island, Atlin Lake, British Columbia, Canada; boulder-sized limestone clast in the Inklin Formation, Whiteavesi Zone, Lower Pliensbachian, Lower Jurassic.

Measurements: See Tables 1 and S1.

Etymology: Named after Paul L. Smith, for his contribution to the Early Jurassic ammonoid paleontology and biostratigraphy of the Canadian Cordillera and his mentoring of students in these topics.

Description: Biconvex shell of unusually large size (up to $90 \mathrm{~mm}$ in length), with subcircular outline. Lateral margins convex with an apical angle of $95-100^{\circ}$. Width and length nearly equal, with largest width attained at mid-length. Ventral and dorsal valves nearly equally convex. Anterior commissure rectimarginate, lateral commissures straight. Beak high and straight, with well-defined beak ridges. Pedicle foramen mesothyrid, deltidial plates present. Both valves ornamented with strong, blunt ribs of rounded triangular profile. Number of ribs between 9 to 15 , more numerous on large specimens. Ribbing irregular due to secondary ribs 
of variable strength which develop by splitting of some of central primaries at $2 / 3$ to $4 / 5$ of length on large-sized specimens.

Internal characters (Figs. 5, 6) of ventral valve include umbonal cavity of laterally expanded oval cross-section. No dental plates. Hinge teeth massive, vertical; denticula not present. Pedicle collar and deltidial plates not recorded. Dorsal valve with strong and high cardinal process, with incipient median groove on its top. Median septum and septalium absent. Outer socket ridges minute. Inner socket ridges well-developed and high; supported by a massive structure emerging as double plates from wall of umbonal cavity of dorsal valve. Hinge plates very wide and nearly horizontal. Crural bases develop nearly medially and somewhat dorsally, giving rise to very long, blade-like, submergiform crura. Their strong curvature and pointed ends leads to near touching of ventral valve, therefore they may be qualified as of ensiform type.

Remarks: The generic attribution to Anarhynchia is well-supported by the external features of biconvex shell of large size, subcircular outline, rectimarginate commissure and strong ribbing, as well as the internal characters such as the elongate, ventrally curved and blade like crura. Apart from the type species $A$. gabbi known from California, a distinctly more coarsely ribbed but as yet unnamed species is reported from Oregon (Manceñido and Dagys 1992; Sandy 2001, 2010). The new species introduced here also differs from $A$. gabbi in its less numerous ribs, whereas its irregular ornamentation manifest in sporadic splitting into secondary ribs of variable strength sets it apart from both congeneric species. It is also distinguished by attaining significantly larger size, and the higher convexity of the shell. External morphometric distinction among the three species of Anarhynchia is summarized in Fig. 7 (see also Table S1). These graphs also demonstrate the greater morphological variability of the new species. Although serial sections are only available for three specimens (Ager 1968; Sandy 2001; and Fig. 5 herein), their internal features are remarkably similar, 
including the characteristic double plates in the umbonal cavity of the dorsal valve, the new species differing mainly in its more prominent hinge teeth and longer submergiform, nearly ensiform crura (Figs. 5, 6). The hinge plates of the new species are wider than those of $A$. gabbi but similar to Peregrinelloidea, nevertheless it is clearly distinguished from the latter genus by the presence of double plates. A specimen tentatively assigned to Anarhynchia is reported from South America, from the Rio Atuel area in Argentina (Manceñido and Dagys 1992). Externally, it falls closest to $A$. gabbi among the three North American species (Table S1).

\section{Carbonate petrography}

The detrital grain fillings of the brachiopods comprise the volumetrically largest part of the samples (Fig. 8A), where these grains are embedded in a micritic matrix (matrix color is brown to orange under CL, see Fig. 9A) that also contains abundant pyrite. The detrital grains display moderate to moderately poor sorting; grain size is dominantly fine to coarse with minor very fine and very coarse grains. Broken and whole crystal euhedra are ubiquitous; consequently, grain shape is predominantly angular to very angular with the siliciclastics exhibiting a pronounced tuffaceous character (Figs. 9A, S1). The modal mineralogy is comprised predominantly of feldspar with lesser lithic grains and minor quartz grains (Fig.

S1). The feldspar component is strongly dominated by plagioclase, the lithic grains are composed almost entirely of volcanic lithologies, and the minor quartz grains appear to be of mostly volcanic derivation.

A banded-fibrous cement phase is identified as early cement, which is almost exclusively developed as isopachous layers of a thickness of c. $1.5 \mathrm{~mm}$ (Fig. 8A). This type of cement most commonly occurs within the brachiopod shells, but occasionally it also lines cavities, or in rare cases it develops on the shells or surrounds shell fragment (Fig. 8B). The staining 
reveals that the banded-fibrous cement is composed of calcite, although it is not homogenous and was subject to recrystallization to varying degrees.

Rarely, micrite with abundant pyrite envelopes the shell or the banded cement in a thickness of 200-250 $\mu \mathrm{m}$ (Fig. 8A). In some cavities the earliest cement phase is followed by two other phases (Fig. 8C). The older of these is brownish in color, shows undulose extinction similar to the banded-fibrous cement, but their crystal habit is different. The younger phase consists of equant calcite cement. After staining, the purple or blue color of the originally brownish cement points to elevated Fe content (Fig. 8D). In some cases, the cavities are filled with only this cement generation inside a thin calcite rim. Apart from these types of cavity filling, yellow calcite was also observed in some vugs (Fig. 8E).

An additional important constituent is the micrite with abundant detrital grains, quartz and plant fragments. It often forms intraclasts of different shapes (Fig. 8F) that are most commonly rounded and $300-400 \mu \mathrm{m}$ in diameter. In the vicinity of intraclasts, the same material forms small (50 $\mu \mathrm{m}$ in diameter) micrite clots (Fig. 8G). These components occur in separate areas, radially surrounded by calcite spar and bordered by banded-fibrous cement (Fig. 8G). Under CL an area composed of recrystallized pyrite-rich micrite shows bright orange luminescence (Fig. 9D).

Although in some cases rounded, sack-shaped traces of boring occur in the cement adjacent to the shell, bioerosion is very rare overall and was observed in only one sample (Fig. 10A). Silicification is a similarly rare feature. An example of silica mineral phases is that grown within a brachiopod shell after the early cement precipitation and sediment filling. This phase is overgrown by quartz crystals (Fig. 8H). Fossils other than brachiopods were observed only in one case, in the form of a thin bivalve shell (Fig. 10B). 


\section{Stable isotope and elemental geochemistry}

The isotopic composition of the carefully drilled, component-specific samples falls into four clusters on the basis of their $\delta^{13} \mathrm{C}$ and $\delta^{18} \mathrm{O}$ values. Notably, these clusters closely correspond to the different components distinguished by carbonate petrography (Table S2,

Fig. 11). The banded-fibrous cement phase yielded the most negative $\delta^{13} \mathrm{C}$ values in the range of -39.8 to $-14.8 \%$ (disregarding a single outlier). The matrix is the second most $\delta^{13} \mathrm{C}$ depleted component, with values between -16.6 to $-4.3 \%$, and their $\delta^{18} \mathrm{O}$ values are also quite negative, similar to the late diagenetic phases. These later phases, the equant calcite spar and the ferroan calcite fall into the same cluster, as they are characterized with $\delta^{18} \mathrm{O}$ values around $-14 \%$ and only slightly depleted $\delta^{13} \mathrm{C}$, in the range of -6.8 to $0.2 \%$. The measured brachiopod shell samples form a distinct group with the least negative $\delta^{13} \mathrm{C}(-5.2$ to $0.7 \%$ o $)$ and $\delta^{18} \mathrm{O}(-7.3$ to $-4.2 \%$ ) values. The $\mathrm{Mg}, \mathrm{Fe}$, and $\mathrm{Mn}$ content measured on selected samples (Table S3) did not reveal any excessive overprint by post-diagenetic fluid mobilization, therefore the stable isotope values are interpreted as reflecting primary, and early and late diagenetic processes.

\section{Discussion}

\section{Anarhynchia as a seep-related brachiopod}

The brachiopod Anarhynchia has been shown to occur in habitats at cold seeps and hydrothermal vents in California and Oregon (Sandy 1995, 2001; Little et al. 1999, 2004), and is unique in occupying both environments which harbor chemosynthesis-based communities (Sandy 2010). Our new record of Anarhynchia extends the known geographic distribution of the genus and sheds new light on some aspects of its taxonomy and paleoecology.

The studied assemblage satisfies the criteria of chemosynthesis-based communities proposed by Sandy (2010): it is of low diversity (in fact monospecific with respect to 
brachiopods), and contains large individuals. The tight packing of individuals together with the size distribution of shells in the boulder suggests preservation of an in-situ community, including a range of ontogenetic states from juveniles to adults (Fig. 3).

Although Lower Jurassic, and specifically Pliensbachian fossiliferous rocks have been intensively studied in the Canadian Cordillera (Smith et al. 1988), brachiopods are relatively rare (Sandy 2001). The active margin setting may not have favored the brachiopods' inclusion in shallow marine benthic communities, where bivalves were clearly much more abundant (Aberhan 1998). The patchy distribution of Anarhynchia, with the here described occurrence complementing its record from California and Oregon, hints at a highly specialized mode of life, indeed it is in agreement with its proposed affinity to cold seep and hydrothermal vent habitats (Little et al. 1999, 2004; Sandy 1995, 2001, 2010). The new species Anarhynchia smithi, and the demonstration of its distinctness from $A$. gabbi and the as yet unnamed species from Oregon establishes the genus as the oldest one among the proposed seep and vent associated brachiopod genera to include three separate species. As all three species are close in their Early Jurassic age range (Pliensbachian, and possibly Sinemurian), it is reasonable to propose that larval hopping allowed for dispersal among scattered cold seep and hydrothermal vent sites along the East Pacific margin, the specific adaptation permitted successful colonization, and allopatric speciation took place. (A notable Cretaceous example of a similarly seep-related dimerelloid brachiopod genus with multiple species is Peregrinella (Sandy and Peckmann 2016)). The new species A. smithi shows the greatest morphologic variability among the three congeneric species, including the range of its shape, convexity, and the irregularity of its secondary ribbing. Such morphological plasticity may be an ecophenotypic expression inherent in the adaptation to the highly specialized and localized seep environment. Crowding of specimens at seep sites may have been an additional factor that led to morphologic variability, as noted for Sulcirostra, another seep-related Early 
Jurassic dimerelloid brachiopod with a western North American occurrence in the Sinemurian of Eastern Oregon (Peckmann et al. 2013)

Although it cannot be conclusive, our new record strengthens the case that Anarhynchia may be an obligate seep or vent dweller, exclusively adapted to chemosynthesis-based ecosystems (Sandy 2010). The giant size of adult individuals ranks the new species among the largest known Mesozoic brachiopods, together with other seep-associated forms such as the Late Triassic Halorella and Early Cretaceous Peregrinella (Sandy 2010). Its growth may have been facilitated by harboring bacterial chemosymbionts, although at present that remains speculative.

The fact that only a single bivalve shell was observed in thin section (Fig. 10B) provides further evidence that Mesozoic chemosynthesis-based communities were strongly dominated by rhynchonellids before the Late Cretaceous (Kiel and Peckmann 2008). The key group is dimerelloids, where Anarhynchia also belongs. As its internal structures are best documented from the new serial sections, it will help assessments of debated evolutionary relationships (Gischler et al. 2003) and the question of monophyly (Sandy 2010) within the group.

\section{Petrographic evidence for cold seep-related carbonate}

Carbonate petrography provides additional evidence for the cold seep-related habitat of the brachiopods, as several hallmarks of seep-related carbonates are best identified by petrography. One typical, albeit in itself not exclusively characteristic feature of ancient and modern seep-related limestones is the occurrence of fibrous cement, which forms isopachous, commonly banded rims and/or shows botryoidal habit (Campbell et al. 2002; Buggisch and Krumm 2005; Teichert et al. 2005; Peckmann et al. 2007, 2011; Kiel and Peckmann 2008; Miyajima et al. 2016). In our samples only the isopachous, banded type was identified.

Staining revealed that this early cement generation is composed of calcite. However, because 
in some of our samples recrystallization was observed, and this type of cement consists of aragonite in modern (Teichert et al. 2005) and relatively young, Late Eocene (Peckmann et al. 2003) and Late Miocene (Miyajima et al. 2016) seep carbonates, it is possible that the cement in our samples may also have had an aragonitic precursor. From botryoidal cement of geologically older seep carbonates, high $\mathrm{Sr}$ content and textural characteristics were suggested as possible indicators of a previous aragonite phase (Peckmann et al. 2001a, 2007; Buggisch and Krumm 2005). Aragonite botryoids were reported from one remarkable Jurassic occurrence (Peckmann et al. 1999). The nonluminescent character of the fibrous calcite was documented by Campbell et al. (2002) and Buggisch and Krumm (2005) as well. Based on elemental geochemistry of the cement phases, Buggisch and Krumm (2005) suggested that the isopachous and botryoidal calcite was previously aragonite and that the low Mn content of the original aragonite is in agreement with the absence of luminescence.

Additional observations, such as the layered composition of cements and micrite, and the abundant pyrite content, are also in agreement with the inferred seep environment (Flügel 2010). Pyrite is thought to be present in high abundance because sulfate-driven anaerobic oxidation of methane is the governing processes of carbonate precipitation at cold seeps (Peckmann et al. 1999).

These features, i.e. the presence of the banded-fibrous cement and abundant pyrite, although often described from seep carbonates, are clearly not restricted to this facies, hence the importance of stable isotope geochemistry in supplying additional evidence. Regarding the microfacies the most reliable component indicative of the origin of seep limestones is the yellow calcite, although different theories have been proposed about its origin. According to Beauchamp and Savard (1992), it develops as a cement phase in pore space, whereas Peckmann et al. (2003) and Birgel et al. (2006) postulate that it replaces aragonite cement, and Campbell et al. (2002) suggest that it replaces previous micrite because in their samples 
the crystals tend to grow from corroded micrite. For our thin sections, where yellow calcite occurs exclusively in vugs, only one of the first two explanations is reasonable. The position of the yellow calcite in the diagenetic sequence remains undetermined in our sample as there is no other carbonate phase in these cavities.

Micrite or microcrystalline carbonate containing pyrite, organic material (such as plant fragments in our samples), and sand-sized grains are often recognized in seep limestones (e.g. Peckmann et al. 2003; Birgel et al. 2006; Joseph et al. 2013; Miyajima et al. 2016). Although only three stable isotope measurements were obtained in this matrix, it is obvious that they tend to show more enriched values than the early banded-fibrous cement phase, but are more depleted than the equant calcite spar of late diagenetic origin. At some places the micrite shows clotted texture which, based on recent occurrences in the Black Sea, is considered as a primary feature related to the carbonate-forming biogeochemical processes (Peckmann et al. 2002). In other areas the micrite forms rounded, peloidal-shaped or more angular intraclasts. Their occurrence in the vicinity of banded-fibrous cement suggests a genetic relationship with fluid flow. The micrite shows orange luminescence as also described by Campbell et al. (2002); they also related this phase to fluid seepage.

Fibrous microcrystalline silica followed by precipitation of euhedral quartz crystals are not unfamiliar features in seep limestones. Based on the observed paragenetic sequence, Kuechler et al. (2012) identified a possible pathway of silicification, and later Smrzka et al. (2015) tested their hypothesis using the computer program PHREEQC. According to these studies, an increase in $\mathrm{pH}$ due to the anaerobic oxidation of methane would lead to dissolution of silica phases, e.g. radiolarian tests. Subsequently, after the anaerobic oxidation of methane the $\mathrm{pH}$ decreases, and it creates conditions favorable to precipitation of silica. However, the genesis of this mineral phase in our samples needs to be explained in another way, as neither the carbonate nor the enclosing sediment contains siliceous microfossils. It can be interpreted 
in the context of the regionally typical diagenetic alteration. This diagenetic relationship is consistent with regional paragenesis for volcaniclastic sandstone (Galloway 1974, 1979; Surdam and Boles 1984; Lee 1992) in general, and the Inklin Formation in the study area in particular, where two phases of silica precipitation were documented in sandstone (Johannson 1994). In a generalized diagenetic sequence for these sediments in active margin setting, the siliceous overgrowths are mostly among the latest phases, as it was also observed in the Inklin Formation. Some degree of porosity and permeability should be inherent in the limestone boulder post-lithification and the source of the silica would then be derived from the same source as the enclosing sediments.

The rarity of bioerosion, and the sometimes sack-shaped borings, which may be caused by fungi, are in agreement with a deep water setting. These characteristics alone would not allow to unambiguously determine the depositional setting, but are in line with the inferences based on the field observations. The outsized nature of the carbonate boulder together with its poorly developed rounding relative to the other clasts are strongly suggestive of a short transport history that would be consistent with entrainment from a seep limestone mound in a deep-water setting during a high-density sediment gravity flow event.

\section{Isotope geochemical evidence for cold seep origin}

Stable isotope geochemistry can yield another crucial, independent line of evidence for the habitat of brachiopods, as carbonate mineral phases constituting cold seep-related limestone inherit the ${ }^{13} \mathrm{C}$-depleted isotopic composition of the parent fluid containing hydrocarbons. Thus their stable isotopic composition, primarily their $\delta^{13} \mathrm{C}$ value, is a valuable tracer of the components formed in the environments of fluid seepage. Biogenic and thermogenic methane, as well as longer-chain hydrocarbons differ in their typical stable isotope signatures (Campbell 2006). Commonly, however, the seep carbonates do not record 
such negative values as these fluids because they become mixed with less depleted carbon derived from seawater or from degradation of organic matter (Campbell 2006; Peckmann et al. 2009, 2011). This mixing can lead to large deviation from the original values, depending on the flow rates and the diffusive or advective nature of the seepage. Peckmann et al. (2009) verified the methane content of the fluids using biomarkers in carbonates with only moderately negative $\delta^{13} \mathrm{C}$ values of $14 \%$.

Many studies documented highly to moderately depleted carbonate carbon isotopic signatures for the banded-fibrous and banded-botryoidal cement phases (e.g. Campbell et al. 2002; Birgel et al. 2006; Hryniewicz et al. 2016; Miyajima et al. 2016; Kiel et al. 2017).

Similar, very negative $\delta^{13} \mathrm{C}$ values recorded in this cement phase of our samples provides evidence for a genetic relationship to methane-bearing seepage even without biomarker data. Isotope values as low as $-39.8 \%$ cannot be explained by any process other than mixing biogenic methane with less depleted sources. Our results, in the range of -37.6 to $-25.9 \%$, closely match those published by Peckmann et al. (1999, 2001b) (-34.8 to -27\%o) (Fig. 11), that could support the role of methane oxidation by additional biomarker studies.

The $\delta^{13} \mathrm{C}$ values measured in the matrix of our samples, although less depleted than those of the early diagenetic banded-fibrous cement phase, are nevertheless negative enough to confidently relate their origin to seep hydrocarbons. Several studies report similar isotopic offset between the matrix and the banded-fibrous cement phase (e.g. Peckmann et al. 2001a; Kiel et al. 2017) (Fig. 11). Campbell et al. (2002) proposed an evolutionary trend of the phases and their $\delta^{13} \mathrm{C}$ and $\delta^{18} \mathrm{O}$ values, suggesting that micrite forms in the early stage of the seepage, followed by yellow calcite and subsequent precipitation of the fibrous calcite phase. This sequence leads to a shift towards more depleted $\delta^{13} \mathrm{C}$ values and parallel enrichment in $\delta^{18} \mathrm{O}$. Both stable isotopes in our samples fit well into this trend, providing explanation for the different degrees of depletion observed. Campbell et al. (2002) also established that the 
equant, blocky calcite spar represents a late diagenetic component, characterized by higher

$\delta^{13} \mathrm{C}$ and lower $\delta^{18} \mathrm{O}$ than the previous phase, commonly exhibiting the lowest $\delta^{18} \mathrm{O}$ values. In our samples the oxygen isotopic values of the late diagenetic phases (i.e. equant spar and ferroan calcite) overlap with those of the micrite, but still show the same trend when comparing with the early cement phase. $\delta^{18} \mathrm{O}$ values as negative as $-14 \%$ indicate a late burial phase, whereas the moderately negative $\delta^{13} \mathrm{C}$ values of $-7 \%$ can also be interpreted to reflect the influence of diagenetic fluids. Other studies reported this phase to show extremely negative $\delta^{13} \mathrm{C}$ values of -38\%o (Campbell et al. 2002) which was hypothesized to indicate either a long-lived seepage (Peckmann et al. 2011) or thermal decarboxylation of organic matter (Peckmann et al. 2001a).

A comparison of the $\delta^{13} \mathrm{C}$ values obtained from our brachiopod shell material reveals that they are either slightly lighter than or similar to those derived from shell calcite of Late Triassic or Jurassic brachiopods from typical marine environments (e.g. Veizer et al. 1999; Korte et al. 2005), suggesting near equilibrium with the contemporaneous seawater. Paull et al. (1985, 1989) and Rio et al. (1992) studied bivalves from modern habitats around hydrothermal vents, containing different chemosynthetic symbionts. The first two groups of bivalves harbored methane-oxidizing bacteria, whereas the third group contained sulfideoxidizing bacteria. The soft tissue of mussels with sulfide-oxidizing symbionts is characterized by $\delta^{13} \mathrm{C}$ values between- 35 to $-30 \%$, whereas those with methane-oxidizing symbionts yielded even lower values, as negative as $-80 \%$. However, the shell of neither groups recorded a significantly depleted signature. Bivalve shells with sulfide-oxidizing bacteria exhibit positive values ( 2 to $4.7 \%$ ) whereas those with methane-oxidizing bacteria yielded slightly negative values (-8\%o to $3 \%$ ). These and subsequent studies of modern organisms (Lietard and Pierre 2009) suggest that even if there is some relationship between the shell and soft part in chemosymbiotic mussels, their shell calcite does not record the 
depleted isotopic signature of the hydrocarbons, unlike the cement phases. During secretion of shell calcite, the diluting effect of ambient seawater likely suppresses the preservation of isotopic composition of seep-derived hydrocarbons. Measured values in shell material from our samples are in agreement with published $\delta^{13} \mathrm{C}$ data on bivalve and brachiopod shells from other seep-related carbonate occurrences, which all fall in a narrow range between -5.7 to 2.2\% (e.g. Kiel and Peckmann 2008; Sandy et al. 2012).

Taken together, the stable isotope characteristics of different carbonate phases analyzed are interpreted as a variable record of microbial oxidation of methane, thus provide independent support for the inferences from paleontology and carbonate petrography. The geochemical signature of the carbonate components and brachiopod shell material is in accordance with other confirmed cold seep-related occurrences.

\section{Conclusions}

The serendipitous discovery of a fossiliferous limestone boulder within a conglomerate bed in the Lower Jurassic Inklin Formation at Atlin Lake precipitated a multidisciplinary study to interpret the origin and significance of this peculiar fossil accumulation. The key findings are as follows.

The monospecific assemblage of rhynchonellid brachiopods, including large-sized specimens, consists of a new species, described here as Anarhynchia smithi sp. nov. Serial sections reveal an internal morphology, notably with prominent, long, blade-like and ventrally curved crura, which allows unambiguous generic assignment of the new species. Anarhnynchia has been previously known from California and Oregon, with another tentative record from Argentina. The new record extends its patchy geographic distribution and supports that the genus is restricted to the East Pacific margin. The conglomerate is Early Pliensbachian in age on the basis of ammonoid biostratigraphy of adjacent finer-grained strata 
within the Inklin Formation, and similarity of detrital grains within the limestone matrix to volcanogenic sandstones in the formation argues for near coeval genesis of limestone. Sedimentological characteristics together with rare bioerosion features suggest a deep water setting.

Because Anarhynchia was previously demonstrated to be restricted to cold seep and hydrothermal vent sites, petrographic and isotope geochemical analyses were conducted to establish if this also applies to its new occurrence. The limestone exhibits a characteristic paragenesis of early and late diagenetic components, including banded-fibrous calcite cement, ferroan calcite, equant calcite spar, observed within the brachiopod shells and vugs together with a micrite matrix. Staining revealed that the banded-fibrous cement phase consists of calcite, with a luminescence pattern indicative of recrystallization possibly from an aragonitic precursor, as suggested by analogous Cenozoic and modern occurrences. These phases commonly form at cold seeps, and the occurrence of yellow calcite is another distinctive and diagnostic feature. The presence of abundant pyrite embedded in micrite matrix is likely derived from sulfate reduction, also in line with the inferred origin as seep limestone.

Results of component-specific stable isotope analyses fully agree with earlier similar studies on seep-related limestones and brachiopods. Derived from bacterial oxidation of methane and other hydrocarbons and mixed with less negative carbon sources, the most depleted $\delta^{13} \mathrm{C}$ values, down to $-39.8 \%$, were measured on the banded-fibrous early cement phase. Subsequently precipitated phases show gradually less negative $\delta^{13} \mathrm{C}$ values. The matrix also bears the isotopic signature of hydrocarbon-related origin, but the ferroan calcite and equant spar were influenced by diagenetic fluids, as evidenced by their more negative $\delta^{18} \mathrm{O}$ values. The least negative carbon isotopic composition is found in brachiopod shell material, indicating effective mixing of seep fluids with ambient seawater. 
These findings strongly support that Anarhynchia is a member of chemosynthesis-based

541 fossil communities. With its length of up to $9 \mathrm{~cm}$, the new species ranks among the largest 542 known Mesozoic brachiopods. Speculation that its giant size owes to harboring chemosymbionts calls for further studies to provide direct evidence. Anarhynchia was cited as a unique example of a genus with affinity to both cold seep and hydrothermal vent. With the demonstration of three separate and distinctive species, it also serves as an example of allopatric speciation among nearly coeval but geographically scattered seep and vent sites along the active margin of western North America. This study adds to a growing database of Mesozoic cold seep biota and provides evidence that prior to the Late Cretaceous, it was strongly dominated by dimerelloid brachiopods.

\section{Acknowledgements}

Paul L. Smith provided long-standing support for our studies of the Cordilleran Jurassic in many ways. Kelly Schreiber is thanked for her enthusiastic assistance in fossil collecting. Insightful discussions on petrography of cold seep carbonates with Axel Munnecke and Jörn Peckmann are gratefully acknowledged. Mariann Bosnakoff provided help with photography. Michelle Coyne curated the fossil type material. Helpful comments by Michael Sandy, an anonymous reviewer, and journal editor Brian Pratt improved the clarity and presentation of this paper. This is MTA-MTM-ELTE Paleo contribution No. 255.

\section{References}

Aberhan, M. 1998. Early Jurassic Bivalvia of western Canada. Part I. Subclasses

Palaeotaxodonta, Pteriomorphia, and Isofilibranchia. Beringeria 21: 57-150. 
Ager, D. 1968. The supposedly ubiquitous Tethyan brachiopod Halorella and its relations. Journal of the Paleontological Society of India 5: 54-70.

Beauchamp, B., and Savard, M. 1992. Cretaceous chemosynthetic carbonate mounds in the Canadian Arctic. Palaios 7: 434-450.

Birgel, D., Peckmann, J., Klautzsch, S., Thiel, V., and Reitner, J. 2006. Anaerobic and aerobic oxidation of methane at Late Cretaceous seeps in the Western Interior Seaway, USA. Geomicrobiology Journal 23: 565-577.

Buggisch, W., and Krumm, S. 2005. Palaeozoic cold seep carbonates from Europe and North Africa - an integrated isotopic and geochemical approach. Facies 51: 566-583.

Campbell, K.A. 2006. Hydrocarbon seep and hydrothermal vent paleoenvironments and paleontology: past developments and future research directions. Palaeogeography, Palaeoclimatology, Palaeoecology 232: 362-407.

Campbell, K.A., and Bottjer, D.J. 1995. Brachiopods and chemosymbiotic bivalves in Phanerozoic hydrothermal vent and cold seep environments. Geology 23: 321-324.

Campbell, K.A., Farmer, J.D., and Des Marais, D. 2002. Ancient hydrocarbon seeps from the Mesozoic convergent margin of California: carbonate geochemistry, fluids and palaeoenvironments. Geofluids 2: 63-94.

Colpron, M., Nelson, J.L., and Murphy, D.C. 2007. Northern Cordilleran terranes and their interactions through time. GSA Today 17: 4-10.

Dagys, A.S. 1968. Yurskie i rannemelovye brakhiopody Severa Sibiri [Jurassic and Early Cretaceous brachiopods from northern Siberia]. Trudy Instituta Geologii I Geofiziki, Akademia Nauk SSSR, Sibiroskoe Otdelenie [Transactions of the Institute of Geology and Geophysics, Academy of Sciences of the USSR, Siberian Branch] 41: 1-167.

English, J.M., Johannson, G.G., Johnston, S.T., Mihalynuk, M.G., Fowler, M., and Wight, K.L. 2005. Structure, stratigraphy and petroleum resource potential of the Central 
Whitehorse Trough, Northern Canadian Cordillera. Bulletin of Canadian Petroleum Geology 53: 130-153.

Flügel, E. 2010. Microfacies of carbonate rocks: Analysis, interpretation and application. $2^{\text {nd }}$ ed. Springer, Berlin.

Galloway, W.E. 1974. Deposition and diagenetic alteration of sandstone in Northeast Pacific arc-related basins: Implications for graywacke genesis. GSA Bulletin 85: 379-390.

Galloway, W.E. 1979. Diagenetic control of reservoir quality in arc-derived sandstones: Implications for petroleum exploration. In Aspects of diagenesis. Edited by P.A. Scholle and P.R. Schluger. The Society of Economic Paleontologists and Mineralogists (SEPM), Tulsa, OK. pp. 251-262.

Gischler, E., Sandy, M.R., and Peckmann, J. 2003. Ibergirhynchia contraria (F. A. Roemer, 1850), an Early Carboniferous seep-related rhynchonellide brachiopod from the Harz Mountains, Germany—a possible successor to Dzieduszyckia? Journal of Paleontology 77: 293-303.

Hryniewicz, K., Bitner, M.A., Durska, E., Hagström, J., Hjálmarsdóttir, H.R., Jenkins, R.G., Little, C.T.S., Miyajima, Y., Nakrem, H.A., and Kaim, A. 2016. Paleocene methane seep and wood-fall marine environments from Spitsbergen, Svalbard. Palaeogeography, Palaeoclimatology, Palaeoecology 462: 41-56.

Johannson, G.G. 1994. Provenance constraints on Early Jurassic evolution of the northern Stikinian arc: Laberge Group, Whitehorse Trough, northwestern British Columbia. MSc thesis, University of British Columbia, Vancouver. p. 299.

Johannson, G.G., Smith, P.L., and Gordey, S.P. 1997. Early Jurassic evolution of the northern Stikinian arc: evidence from the Laberge Group, northwestern British Columbia. Canadian Journal of Earth Sciences 34: 1030-1057. 
610

Johnston, S.T. 2008. The Cordilleran Ribbon Continent of North America. Annual Review of Earth and Planetary Sciences 36: 495-530.

Joseph, C., Campbell, K.A., Torres, M.E., Martin, R.A., Pohlman, J.W., Riedel, M., and Rose, K. 2013. Methane-derived authigenic carbonates from modern and paleoseeps on the Cascadia margin: Mechanisms of formation and diagenetic signals. Palaeogeography, Palaeoclimatology, Palaeoecology 390: 52-67.

Kiel, S. (ed). 2010a. The Vent and Seep Biota. Aspects from Microbes to Ecosystems. Springer, Heidelberg.

Kiel, S. 2010b. On the potential generality of depth-related ecologic structure in cold-seep communities: Cenozoic and Mesozoic examples. Palaeogeography, Palaeoclimatology, Palaeoecology 295: 245-257.

Kiel, S., and Peckmann, J. 2008. Paleoecology and evolutionary significance of an Early Cretaceous Peregrinella-dominated hydrocarbon-seep deposit on the Crimean Peninsula. Palaios 23: 751-759.

Kiel, S., Glodny, J., Birgel, D., Bulot, L.G., Campbell, K.A., Gaillard, C., Graziano, R., Kaim, A., Lazăr, I., Sandy, M.R., and Peckmann, J. 2014. The paleoecology, habitats, and stratigraphic range of the enigmatic Cretaceous brachiopod Peregrinella. PLoS ONE 9(10): e109260. doi: 10.1371/journal.pone.0109260.

Kiel, S., Krystyn, L., Demirtaş, F., Koşun, E., and Peckmann, J. 2017. Late Triassic molluskdominated hydrocarbon-seep deposits from Turkey. Geology 45: 751-754.

Korte, C., Kozur, H.W., and Veizer, J. 2005. $\delta^{13} \mathrm{C}$ and $\delta^{18} \mathrm{O}$ values of Triassic brachiopods and carbonate rocks as proxies for coeval seawater and palaeotemperature. Palaeogeography, Palaeoclimatology, Palaeoecology 226: 287-306. 
Kuechler, R.R., Birgel, D., Kiel, S., Freiwald, A., Goedert, J.L., Thiel, V., and Peckmann, J. 2012. Miocene methane-derived carbonates from southwestern Washington, USA and a model for silicification at seeps. Lethaia 45: 259-273.

Lee, Y.I.L. 1992. Diagenesis of deep-sea volcaniclastic sandstones. In Diagenesis. Edited by K.H. Wolfe and G.V. Chiligarian. Elsevier, New York. pp. 253-290.

Lietard, C., and Pierre, C. 2009. Isotopic signatures $\left(\delta^{18} \mathrm{O}\right.$ and $\left.\delta^{13} \mathrm{C}\right)$ of bivalve shells from cold seeps and hydrothermal vents. Geobios 42: 209-219.

Little, C.T.S., Herrington, R.J., Haymon, R.M., and Danelian, T. 1999. Early Jurassic hydrothermal vent community from the Franciscan Complex, San Rafael Mountains, California. Geology 27: 167-170.

Little, C.T., Danelian, T., Herrington, R.J., and Haymon, R.M. 2004. Early Jurassic hydrothermal vent community from the Franciscan Complex, California. Journal of Paleontology 78: 542-559.

Manceñido, M.O., and Dagys, A.S. 1992. Brachiopods of the circum-Pacific. In The Jurassic of the Circum-Pacific. Edited by G.E.G. Westermann. Cambridge University Press, Cambridge. pp. 328-333.

Manceñido, M.O., and Owen, E.F. 2001. Post-Palaeozoic Rhynchonellida (Brachiopoda): classification and evolutionary background. In Brachiopods Past and Present. Edited by C.H.C. Brunton and L.R.M. Cocks and S.L. Long. Taylor \& Francis, London. pp. 189-200. Miyajima, Y., Watanabe, Y., Yanagisawa, Y., Amano, K., Hasegawa, T., and Shimobayashi, N. 2016. A late Miocene methane-seep deposit bearing methane-trapping silica minerals at Joetsu, central Japan. Palaeogeography, Palaeoclimatology, Palaeoecology 455: 1-15.

Monger, J., and Price, R. 2002. The Canadian Cordillera: geology and tectonic evolution. Canadian Society of Exploration Geophysicists Recorder 27: 17-36. 
Monger, J.W.H., Wheeler, J.O., Tipper, H.W., Gabrielse, H., Harms, T., Struik, L.C., Campbell, R.B., Dodds, C.J., Gehrels, G.E., and O’Brien, J. 1991. Cordilleran terranes. In: Upper Devonian to Middle Jurassic assemblages. In Geology of the Cordilleran Orogen in Canada. Edited by H. Gabrielse and C.J. Yorath. Geological Survey of Canada, (also Geological Society of America). pp. 281-327.

Paull, C.K., Jull, A.J.T., Toolin, L.J., and Linick, T. 1985. Stable isotope evidence for chemosynthesis in an abyssal seep community. Nature 317: 709-711.

Paull, C.K., Martens, C.S., Chanton, J.P., Neumann, A.C., Coston, J., Jull, A.J.T., and Toolin, L.J. 1989. Old carbon in living organisms and young $\mathrm{CaCO}_{3}$ cements from abyssal brine seeps. Nature 342: 166-168.

Peckmann, J., Thiel, V., Michaelis, W., Clari, P., Gaillard, C., Martire, L., and Reitner, J. 1999. Cold seep deposits of Beauvoisin (Oxfordian; southeastern France) and Marmorito (Miocene; northern Italy): microbially induced authigenic carbonates. International Journal of Earth Sciences 88: 60-75.

Peckmann, J., Gischler, E., Oschmann, W., and Reitner, J. 2001a. An Early Carboniferous seep community and hydrocarbon-derived carbonates from the Harz Mountains, Germany. Geology 29: 271-274.

Peckmann, J., Reimer, A., Luth, U., Luth, C., Hansen, B., Heinicke, C., Hoefs, J., and Reitner, J. 2001b. Methane-derived carbonates and authigenic pyrite from the northwestern Black Sea. Marine Geology 177: 129-150.

Peckmann, J., Goedert, J.L., Thiel, V., Michaelis, W., and Reitner, J. 2002. A comprehensive approach to the study of methane-seep deposits from the Lincoln Creek Formation, western Washington State, USA. Sedimentology 49: 855-873. 
Peckmann, J., Goedert, J.L., Thiel, V., Schmale, O., Rau, W.W., and Michaelis, W. 2003. The Late Eocene 'Whiskey Creek' methane-seep deposit (western Washington State). Facies 48: $223-239$.

Peckmann, J., Campbell, K.A., Walliser, O.H., and Reitner, J. 2007. A Late Devonian hydrocarbon-seep deposit dominated by dimerelloid brachiopods, Morocco. Palaios 22: $114-122$

Peckmann, J., Birgel, D., and Kiel, S. 2009. Molecular fossils reveal fluid composition and flow intensity at a Cretaceous seep. Geology 37: 847-850.

Peckmann, J., Kiel, S., Sandy, M., Taylor, D., and Goedert, J. 2011. Mass occurrences of the brachiopod Halorella in Late Triassic methane-seep deposits, eastern Oregon. The Journal of Geology 119: 207-220.

Peckmann, J., Sandy, M.R., Taylor, D.G., Gier, S., and Bach, W. 2013. An Early Jurassic brachiopod-dominated seep deposit enclosed by serpentinite, eastern Oregon, USA. Palaeogeography, Palaeoclimatology, Palaeoecology 390: 4-16.

Rio, M., Roux, M., Renard, M., and Schein, E. 1992. Chemical and isotopic features of present day bivalve shells from hydrothermal vents or cold seeps. Palaios 7: 351-360.

Sandy, M.R. 1986. Brachiopod systematics and the transverse serial sectioning method: some recommendations for this technique and clarification of a taxonomic problem assisted by this method. In Les Brachiopdes fossiles et actuels. Edited by P.R. Racheboeuf and C.C. Emig. pp. 143-150.

Sandy, M.R. 1995. A review of some Palaeozoic and Mesozoic brachiopods as members of cold seep chemosynthetic communities:"unusual" palaeoecology and anomalous palaeobiogeographic patterns explained. Földtani Közlöny (Bulletin of the Hungarian Geological Society) 125: 241-258. 
Sandy, M.R. 2001. Mesozoic articulated brachiopods from the Western Cordillera of North America: their significance for palaeogeographic and tectonic reconstruction, palaeobiogeography and palaeoecology. In Brachiopods Past and Present. Edited by C.H.C. Brunton and L.R.M. Cocks and S.L. Long. Taylor \& Francis, London. pp. 394-410. Sandy, M.R. 2010. Brachiopods from ancient hydrocarbon seeps and hydrothermal vents. In The Vent and Seep Biota. Edited by S. Kiel. Springer, Heidelberg. pp. 279-314.

Sandy, M.R., and Peckmann, J. 2016. The Early Cretaceous brachiopod Peregrinella from Tibet: a confirmed hydrocarbon-seep occurrence for a seep-restricted genus. Paläontologische Zeitschrift 90: 691-699.

Sandy, M., Lazăr, I., Peckmann, J., Birgel, D., Stoica, M., and Roban, R. 2012. Methane-seep brachiopod fauna within turbidites of the Sinaia Formation, Eastern Carpathian Mountains, Romania. Palaeogeography, Palaeoclimatology, Palaeoecology 323: 42-59.

Sigloch, K., and Mihalynuk, M.G. 2013. Intra-oceanic subduction shaped the assembly of Cordilleran North America. Nature 496: 50-56.

Smith, P.L., Tipper, H.W., Taylor, D.G., and Guex, J. 1988. An ammonite zonation for the Lower Jurassic of Canada and the United States: the Pliensbachian. Canadian Journal of Earth Sciences 25: 1503-1523.

Smrzka, D., Kraemer, S., Zwicker, J., Birgel, D., Fischer, D., Kasten, S., Goedert, J., and Peckmann, J. 2015. Constraining silica diagenesis in methane-seep deposits. Palaeogeography, Palaeoclimatology, Palaeoecology 420: 13-26.

Surdam, R.C., and Boles, J.R. 1979. Diagenesis of volcanic sandstones. In Aspects of diagenesis. Edited by P.A. Scholle and P.R. Schluger. The Society of Economic Paleontologists and Mineralogists (SEPM), Tulsa, OK. pp. 227-242. 
727 Teichert, B.M., Bohrmann, G., and Suess, E. 2005. Chemoherms on Hydrate Ridge - unique

728 microbially-mediated carbonate build-ups growing into the water column.

729 Palaeogeography, Palaeoclimatology, Palaeoecology 227: 67-85.

730 Veizer, J., Ala, D., Azmy, K., Bruckschen, P., Buhl, D., Bruhn, F., Carden, G.A.F., Diener,

731 A., Ebneth, S., Godderis, Y., Jasper , T., Korte, C., Pawellek, F., Podlaha, O.G., and

732 Strauss, H. 1999. ${ }^{87} \mathrm{Sr} /{ }^{86} \mathrm{Sr}, \delta^{13} \mathrm{C}$ and $\delta^{18} \mathrm{O}$ evolution of Phanerozoic seawater. Chemical

733 Geology 161: 59-88.

734 Wight, K.L., English, J.M., and Johnston, S.T. 2004. Structural relationship between the

735 Laberge Group and Sinwa Formation on Copper Island, southern Atlin Lake, northwest

736 British Columbia. Resource Development and Geoscience Branch, B.C. Ministry of

737 Energy and Mines, Summary of Activities 2004: 113-120.

738 Williams, A., Brunton, C.H.C., and Carlson, S.J. 2002. Treatise on Invertebrate

739 Palaeontology. Part H, Brachiopoda (Revised), Volume 4, Rhynchonelliformea (part).

740 Geological Society of America and University of Kansas, Boulder, CO and Lawrence, KA. 
743 Table 1. Measurements of Anarhynchia smithi n. sp.

\begin{tabular}{lcccc}
\hline $\begin{array}{l}\text { GSC type No. } \\
\text { or specimen No. }\end{array}$ & $\begin{array}{c}\text { Length } \\
(\mathrm{mm})\end{array}$ & $\begin{array}{c}\text { Width } \\
(\mathrm{mm})\end{array}$ & $\begin{array}{c}\text { Thickness } \\
(\mathrm{mm})\end{array}$ & $\begin{array}{c}\text { No. of } \\
\text { primary ribs }\end{array}$ \\
\hline GSC 139294 $(p t)$ & 41.5 & 38.5 & 23.8 & 15 \\
GSC 139295 $(h t)$ & 28 & 26.5 & 12.5 & 10 \\
GSC 139296 & 43 & 53 & 30.5 & 14 \\
GSC 139297 $(p t)$ & 52.5 & 54 & - & 12 \\
GSC 139298 $(p t)$ & 62 & 63 & 34 & 11 \\
GSC 139299 & 35 & 38 & - & 10 \\
GSC 139300 & 90 & - & 19 & 11 \\
C-203329/D & 40.3 & - & - & 12 \\
C-203329/I & 28.3 & 31 & - & 9 \\
C-203329/K & - & 39 & - & 12 \\
C-203329/L & 39 & 40 & & 9 \\
\hline
\end{tabular}

${ }^{\text {a }} h t$ : holotype, $p t$ : paratype 


\section{Figure captions}

Fig. 1. Location map and geologic context of the occurrence of Anarhynchia smithi n. sp. (A) Schematic distribution of the major tectonostratigraphic terranes (CC - Cache Creek; QN Quesnel; ST - Stikine; YT - Yukon-Tanana) in the Intermontane Belt of the Canadian Cordillera (after Nelson and Colpron 2007). Rectangle marks the area shown in panel B. (B) Regional geological setting of the main tectonostratigraphic units in the southern Atlin Lake area (after Johannson et al. 1997). Rectangle marks the area shown in panel C. (C) Simplified geological map of Copper Island, Atlin Lake (after Wight et al. 2004), showing the brachiopod locality and adjacent ammonite localities of different Pliensbachian ammonite zones (after Johannson 1994).

Fig. 2. Outcrop and host rock of the Anarhynchia-bearing boulder. (A) View of outcrop of conglomerate beds in the Inklin Formation in Copper Island at Atlin Lake. Note circled hammer for scale. (B) Coarse pebble-cobble conglomerate with sparse boulders showing typical range of clast-size, shape, and distribution. The large outsized boulder in center of photo is of the same approximate size as the Anarhynchia-bearing boulder.

Fig. 3. Anarhynchia-bearing boulder displaying range of juvenile and mature forms indicative of an in-situ accumulation. The well-developed rounding/sphericity of other conglomerate clasts is not evident on boulder surfaces. (A) View of weathered surface of boulder. (B) Drawing of Anarhynchia shells and fragments within the boulder.

Fig. 4. Anarhynchia smithi n. sp. All figures are natural size, scale bar is $1 \mathrm{~cm}$. GSC locality No. C-203329, Copper Island in Atlin Lake, B.C., Lower Pliensbachian. Specimens are identified with Geological Survey of Canada type numbers. 1. GSC 139294, paratype, serially 
sectioned specimen; a: dorsal view, b: ventral view, c: lateral view. 2. GSC 139295, holotype; a: dorsal view, b: ventral view, c: anterior view, d: lateral view. 3. GSC 139296, dorsal view. 4. GSC 139297, paratype; a: ventral view, b: dorsal view of fragmentary valve and beak. 5 . GSC 139298, paratype; a: dorsal view, b: ventral view. 6. GSC 139299, a: ventral view, b: dorsal view of beak. 7. GSC 139300, ventral view.

Fig. 5. Transverse serial sections of a paratype specimen (GSC 139294) of Anarhynchia smithi $\mathrm{n}$. sp. See text for description.

Fig. 6. Reconstruction of the crura of Anarhynchia smithi n. sp., on the basis of serial sections. Note submerginiform habit with end of blades approaching the ventral valve, hence also resembling ensiform type. See text for discussion.

Fig. 7. Comparison of morphometric data of Anarhynchia smithi n. sp. (solid squares, magenta in color) with other North American species in the genus. A. gabbi is marked by solid blue triangles, whereas solid blue circles indicate $A$. cf. gabbi specimens from the hydrothermal vent deposit of Little et al. $(1999,2004)$. A yet unnamed third species from Oregon, $A$. sp. is denoted by brown unfilled squares. Convex hulls show minimal or no overlap between species. Source data and references are listed in Table S1. (A) Graph showing number of primary ribs vs. length of shell. (B) Graph showing convexity (ratio of thickness and average of length and width) vs. width/length ratio $[\mathrm{T} /((\mathrm{L}+\mathrm{W}) / 2) \mathrm{vs}$. W/L].

Fig. 8. Photomicrographs illustrating characteristic petrographic features of Anarhynchia shells and their filling. All scale bars $600 \mu \mathrm{m}$. (A) Quartz-, feldspar-, and pyrite-rich filling of the brachiopod shell. Banded-fibrous cement $(b f c)$ developed as isopachous layer, and subsequently formed dark micrite with abundant pyrite. Plane polarized light. (B) Brachiopod 
shell fragments $(s h)$ surrounded by isopachous fibrous cement phase $(b f c)$ and equant calcite spar (ec). Cross polarized light. (C) The paragenetic sequence of cements. Banded-fibrous cement $(b f c)$ is the earliest phase, followed by ferroan calcite $(f c)$ and equant calcite spar $(e c)$. $s h$ - brachiopod shell. Plane polarized light. (D) The same three cement phases as in (C) after staining. Note the purple color of the originally brownish cement due to its Fe content. $b f_{c}-$ banded-fibrous cement, $f c$ - ferroan calcite, $e c$ - equant calcite spar. (E) Cavity filled by yellow calcite. Plane polarized light. (F) Micrite with abundant detrital grains, quartz and plant fragments, forming intraclasts (ic) of commonly, but not exclusively, rounded shapes. sh - brachiopod shell, $b f c$ - banded-fibrous cement, $e c$ - equant calcite. Cross polarized light. (G) Detrital-rich micrite formed beside rounded clasts of micrite clots, which are surrounded by calcite. Areas containing numerous clasts and clots are bordered by banded-fibrous cement $(b f c)$. Plane polarized light. (H) Fibrous microcrystalline silica $(f m s)$ grown inside a brachiopod shell and overgrown by quartz crystals $(q)$. Cross polarized light.

Fig. 9. Photomicrographs illustrating characteristic petrographic features in cathodoluminescence (CL). All scale bars $500 \mu \mathrm{m}$. (A) Matrix containing abundant angular mineral grains showing brown to orange luminescence. (B) The same cement phases as in Fig. $8 \mathrm{C}$, D under CL. The banded fibrous cement $(b f c)$ is nonluminescent. The cement phase containing some $\mathrm{Fe}(f c)$ shows different luminescence. The equant calcite spar $(e c)$ shows bright luminescence. (C, D) The same phases in cross polarized light and under CL, showing the recrystallized development of the banded fibrous cement $(b f c)$ and micrite with abundant fine detritus $(m)$. Where the fibrous cement is replaced by coarser calcite crystals the CL image is mottled with pale-orange, brown color. The micrite with abundant pyrite shows bright-orange luminescence. 
813 Fig. 10. Miscellaneous rare features observed in thin sections. All scale bars $600 \mu \mathrm{m}$. (A) 814 Rounded and sack-shaped traces of borings. (B) Thin bivalve shell, surrounded by banded815 fibrous cement. Note that contrary to the more common brachiopod shells, the bivalve shell 816 lacks fibrous microstructure.

817 Fig. 11. $\delta^{18} \mathrm{O}-\delta^{13} \mathrm{C}$ cross plot of measured component-specific stable isotope ratios and their al. 2017. 


\section{List of Supplementary material}

826

827

828

829

830

831

832

Fig. S1. Photomicrographs illustrating characteristic petrographic features and tuffaceous nature of a detrital grain-dominated part in the filling of a brachiopod shell. (A) Plane polarized light; (B) Cross polarized light. Scale bar is $600 \mu \mathrm{m}$.

Table S1. Measurements of all Anarhynchia specimens in this study and figured in published sources.

Table S2. Stable isotope data of carbonate phases of Anarhynchia smithi specimens.

Table S3. Elemental geochemical data of carbonate phases of Anarhynchia smithi specimens. 


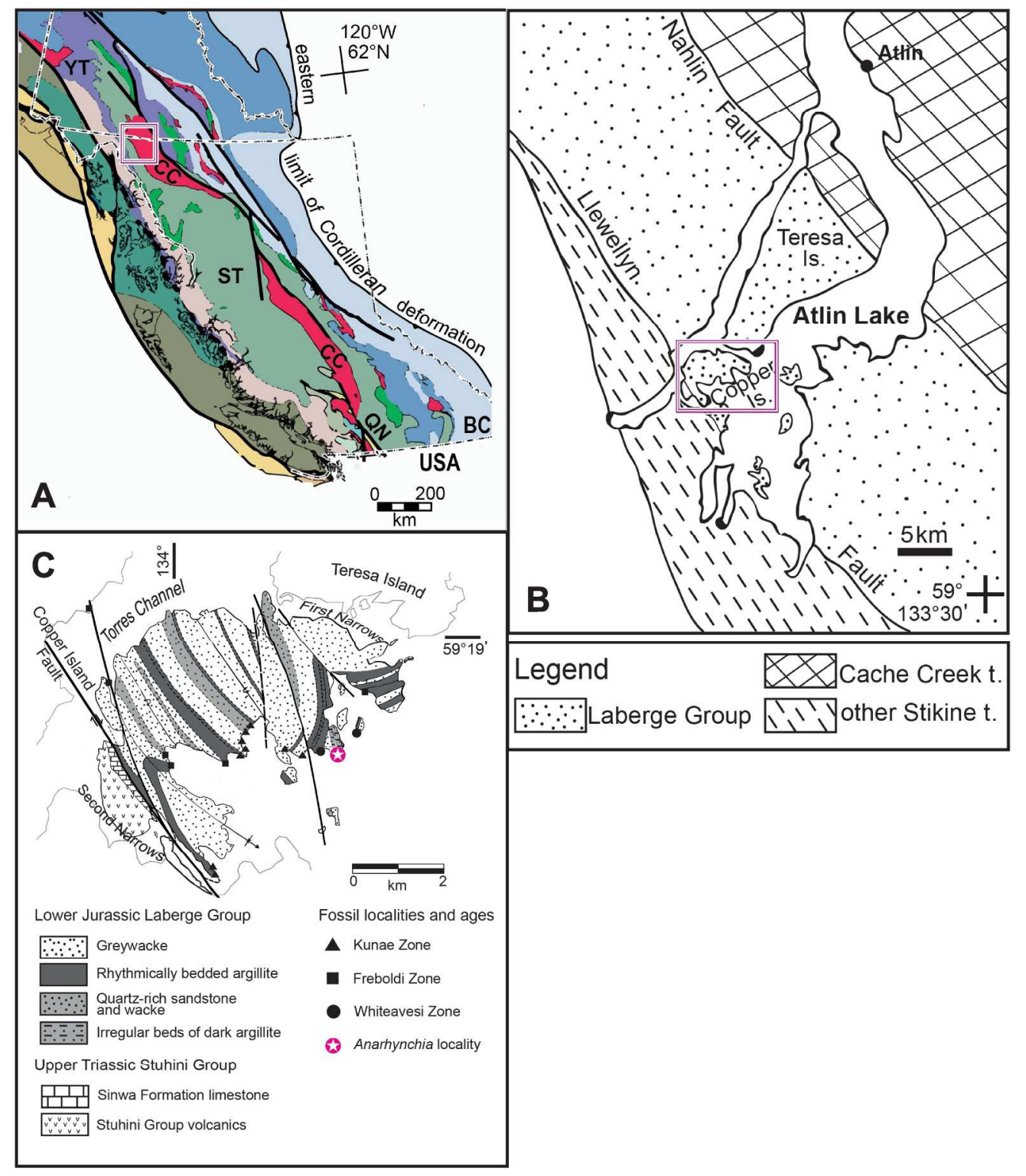

Fig. 1: Location map

$214 \times 249 \mathrm{~mm}(300 \times 300$ DPI $)$ 

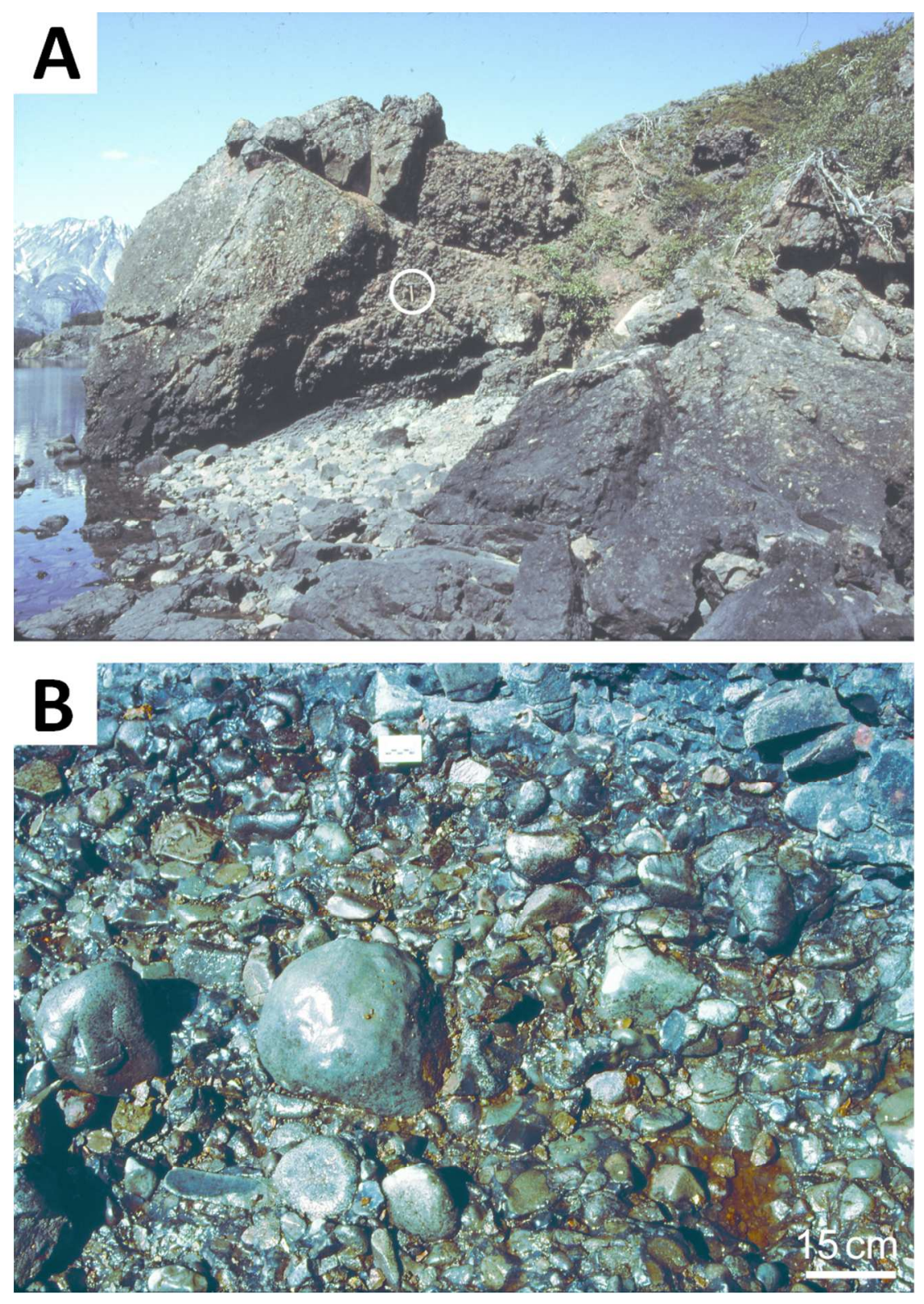

Fig. 2: View of outcrop

$86 \times 122 \mathrm{~mm}(300 \times 300 \mathrm{DPI})$ 

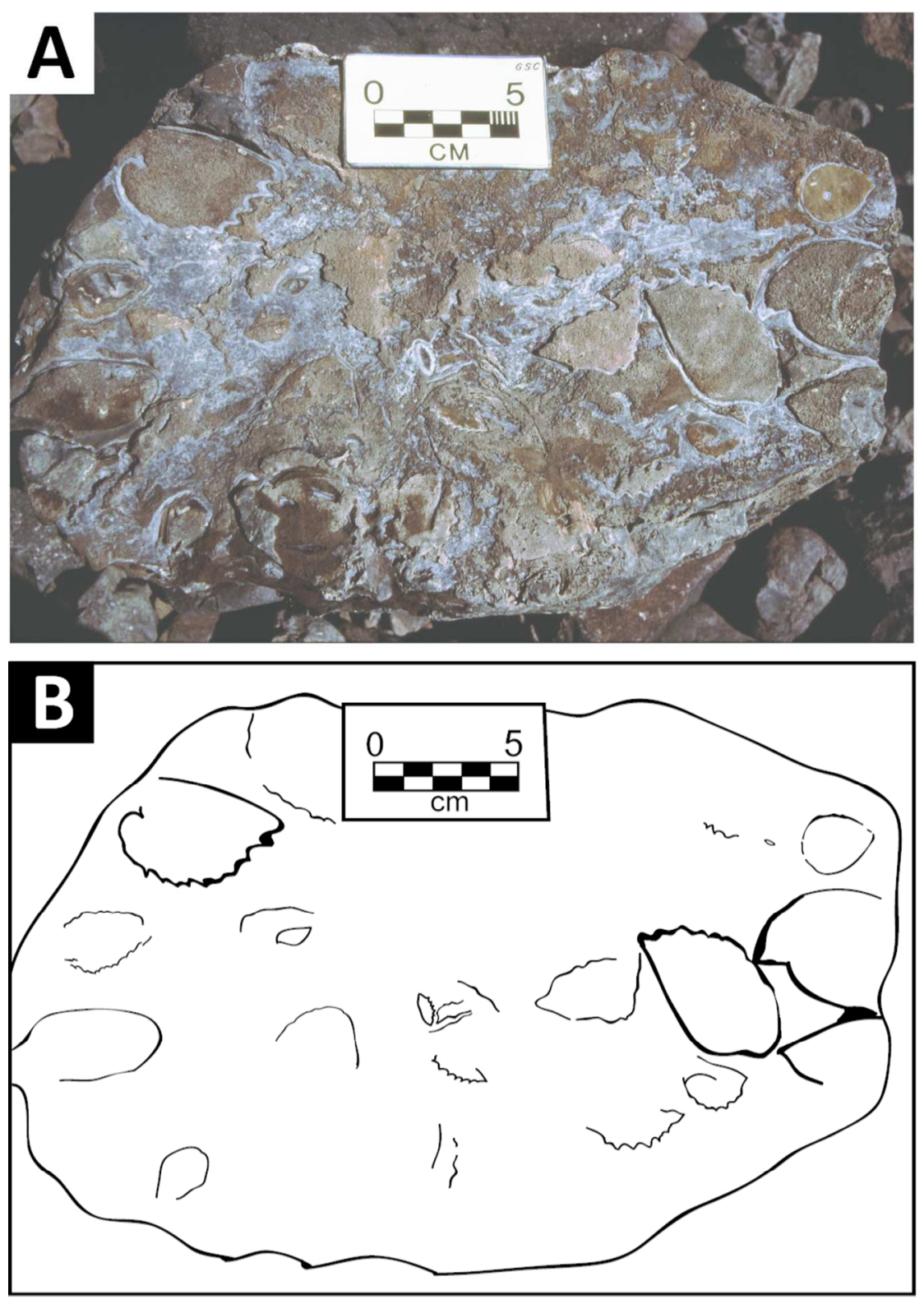

Fig. 3: Boulder with brachiopods

$86 \times 122 \mathrm{~mm}(300 \times 300 \mathrm{DPI})$ 


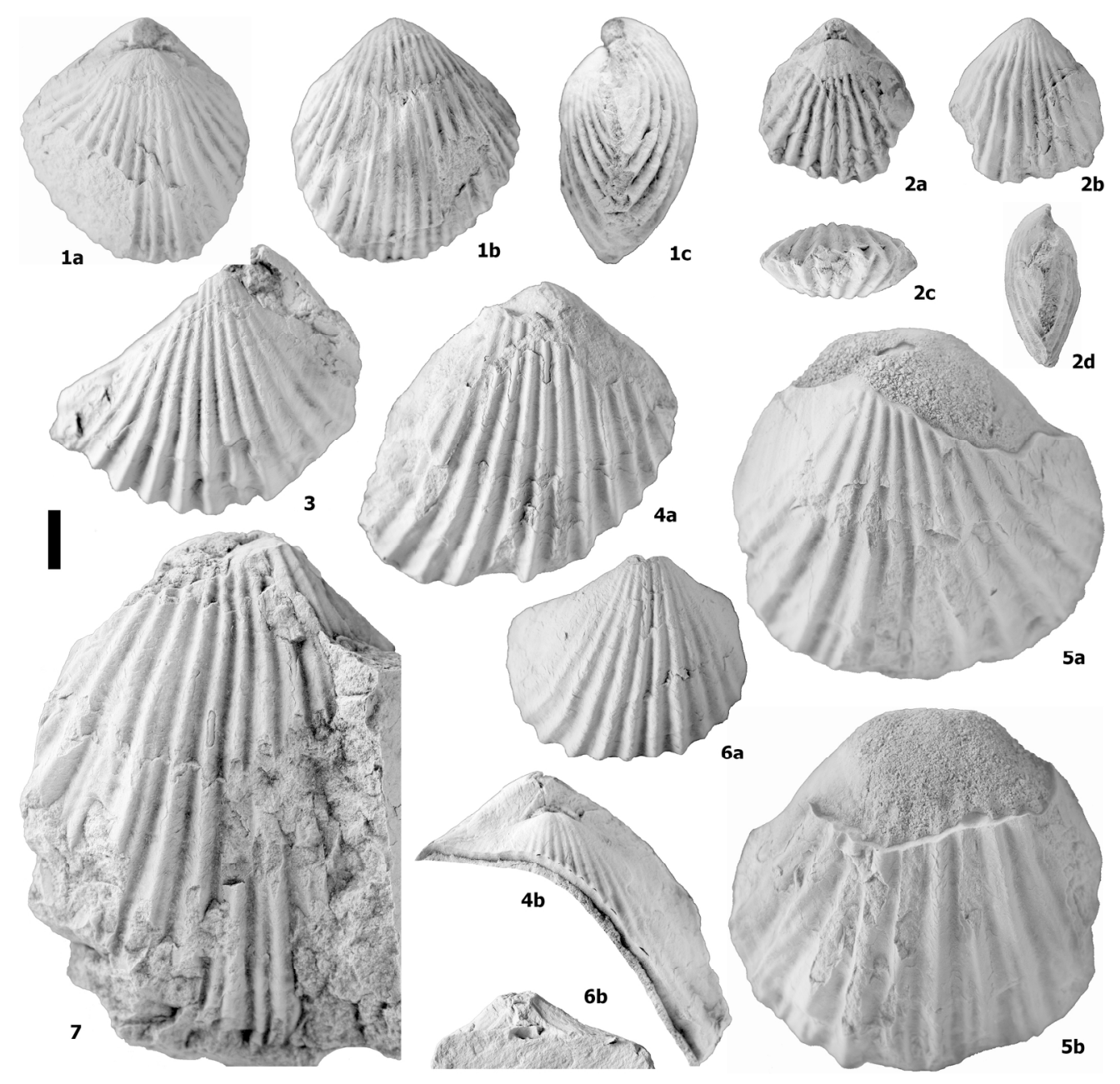

Fig. 4: Photographs of Anarhynchia smithi n. sp.

$176 \times 172 \mathrm{~mm}(300 \times 300$ DPI $)$ 


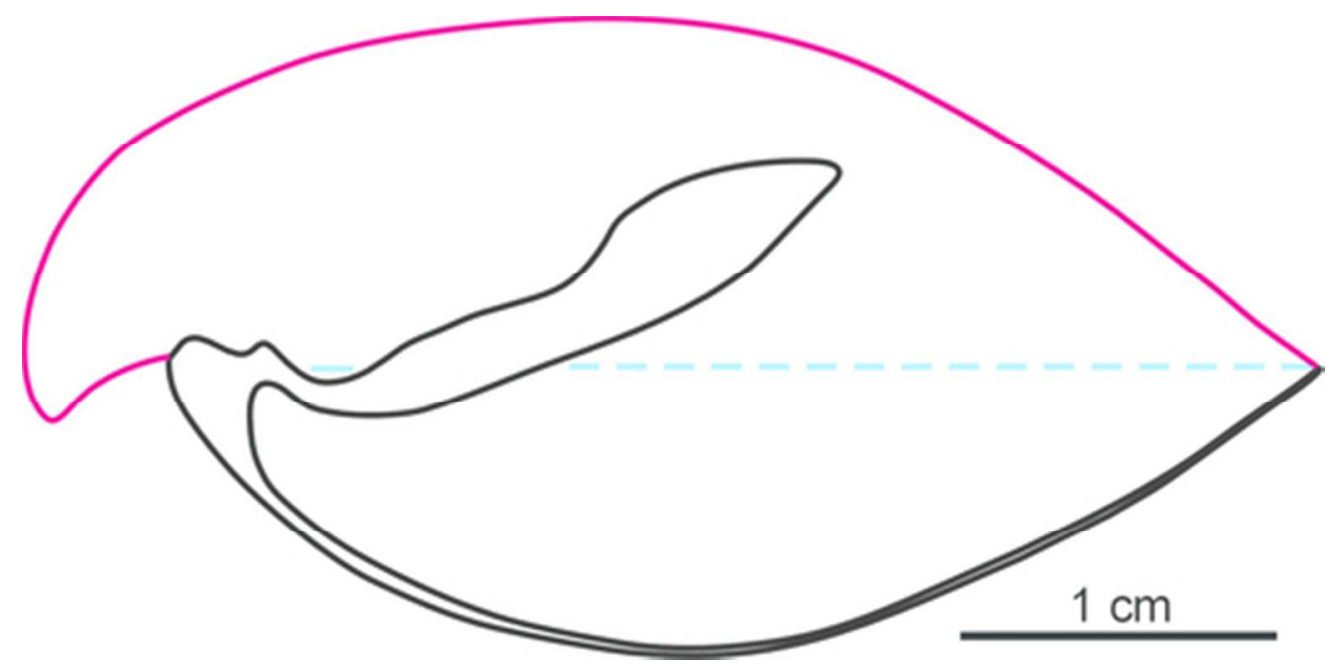

Fig. 6: Reconstruction of the crura of Anarhynchia smithi n. sp.

$42 \times 20 \mathrm{~mm}(300 \times 300 \mathrm{DPI})$ 

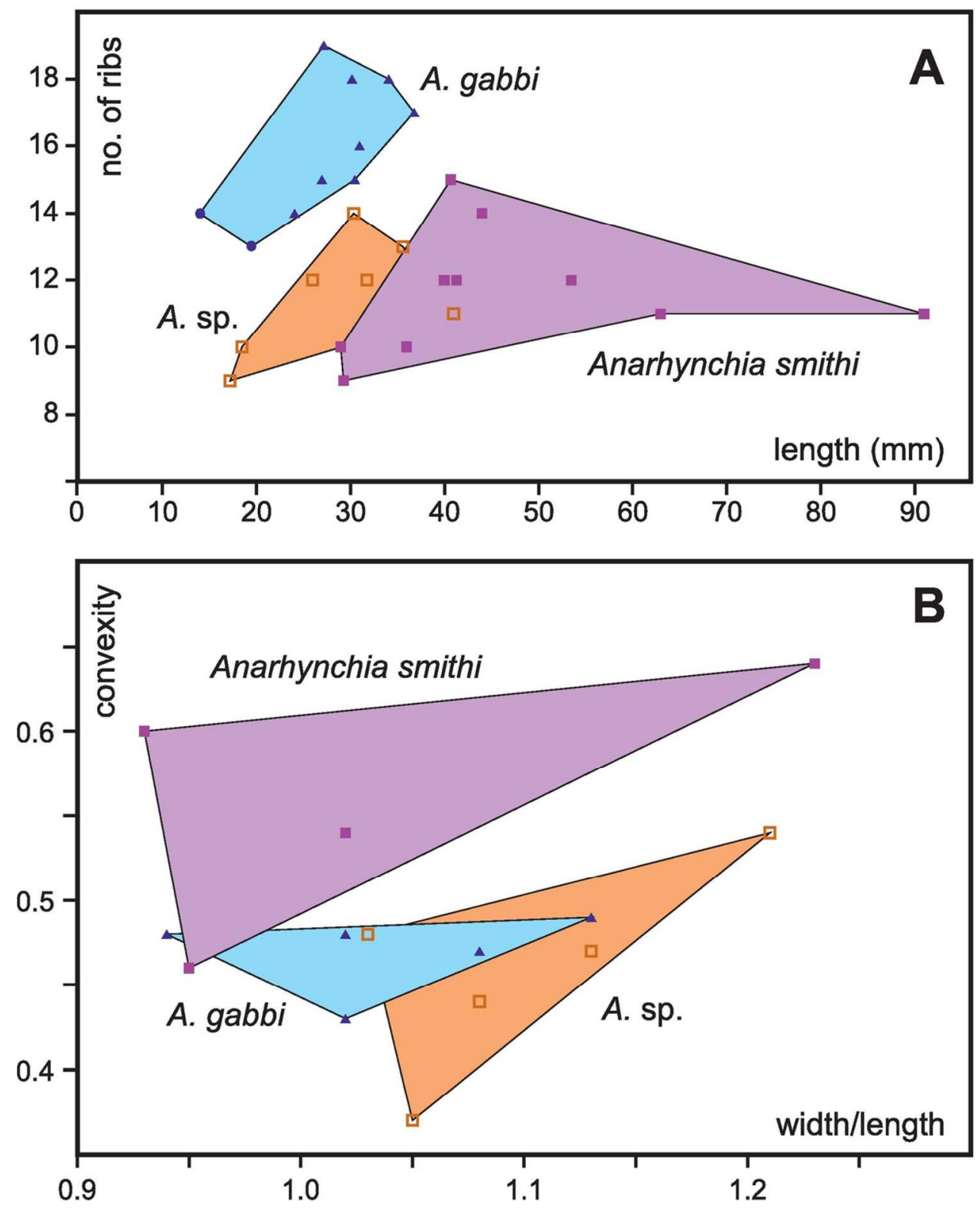

Fig. 7: Comparison of morphometric data of Anarhynchia $105 \times 130 \mathrm{~mm}(300 \times 300 \mathrm{DPI})$ 

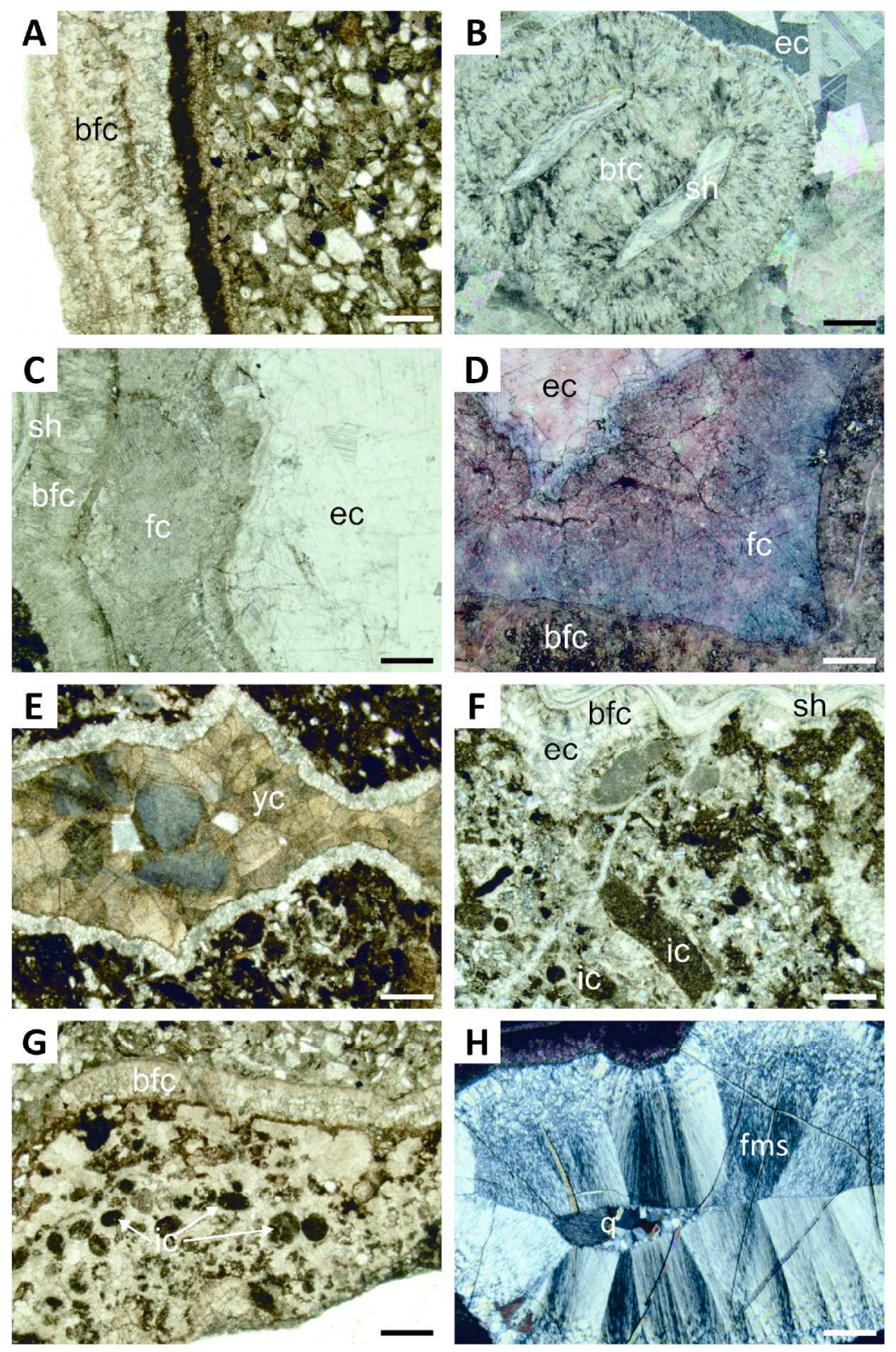

Fig. 8: Photomicrographs illustrating characteristic petrographic features of Anarhynchia shells and their filling

$155 \times 236 \mathrm{~mm}(300 \times 300 \mathrm{DPI})$ 

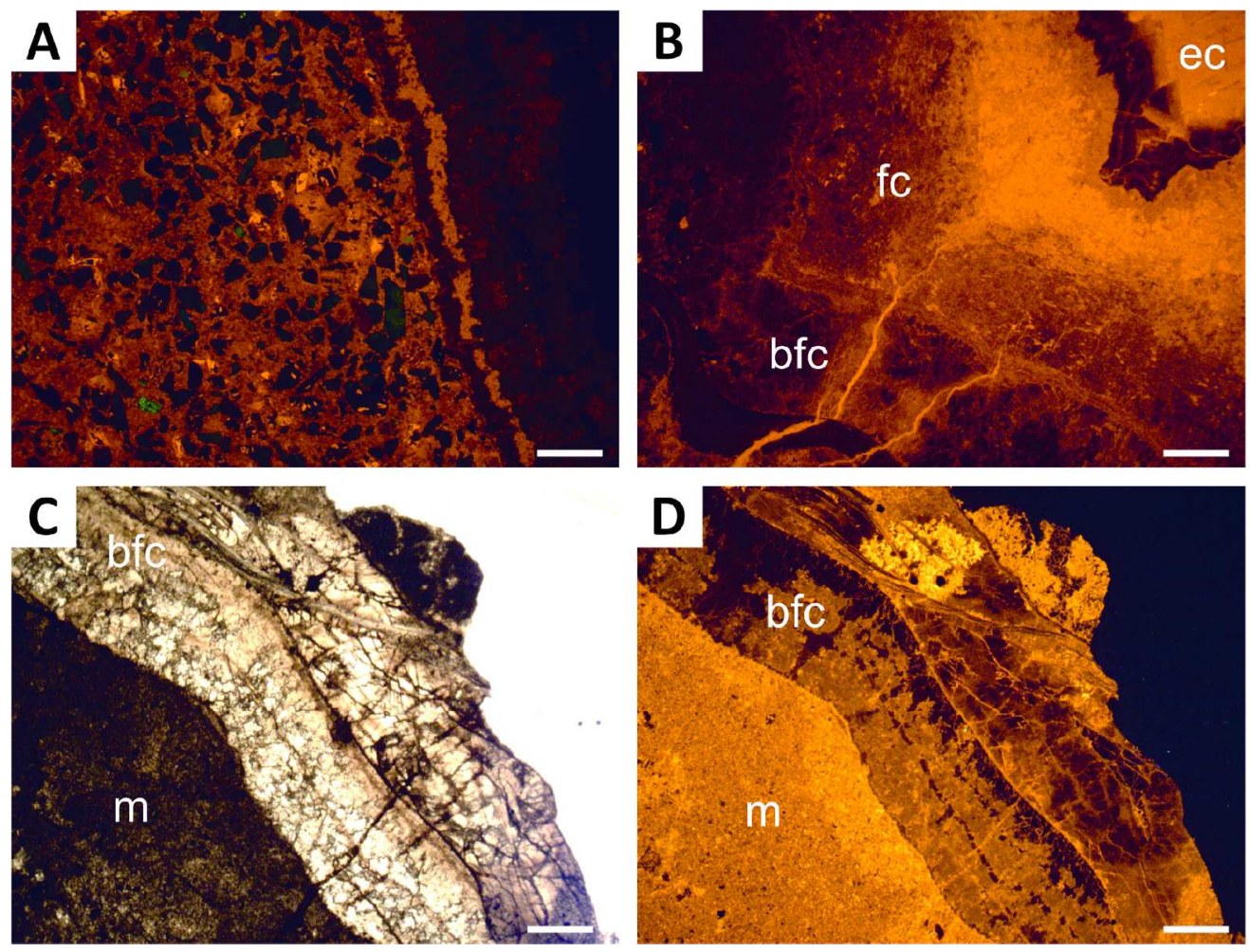

Fig. 9: Photomicrographs illustrating characteristic petrographic features in cathodoluminescence $182 \times 137 \mathrm{~mm}(300 \times 300$ DPI $)$ 

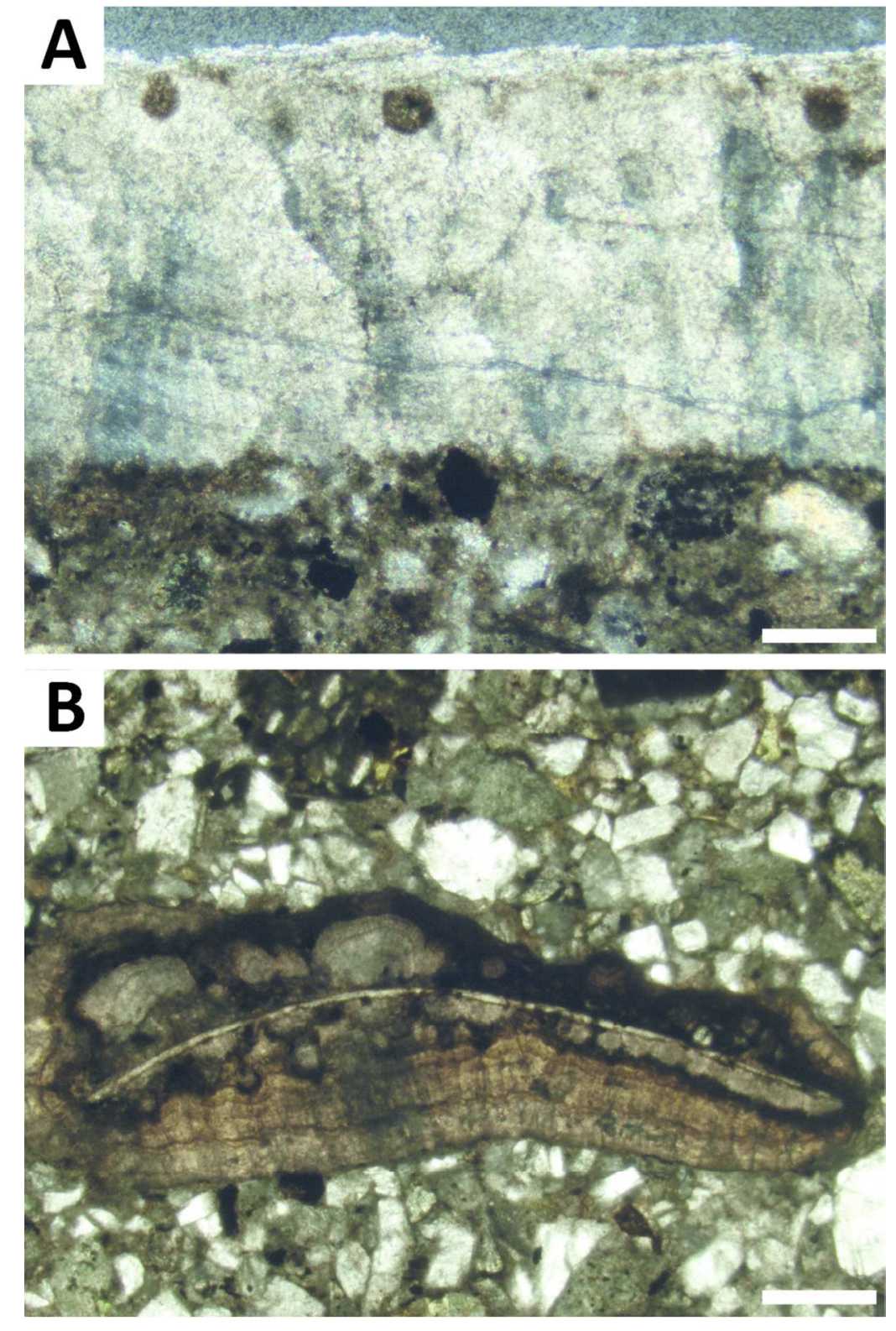

Fig. 10: Miscellaneous rare features observed in thin sections $86 \times 130 \mathrm{~mm}(300 \times 300$ DPI $)$ 


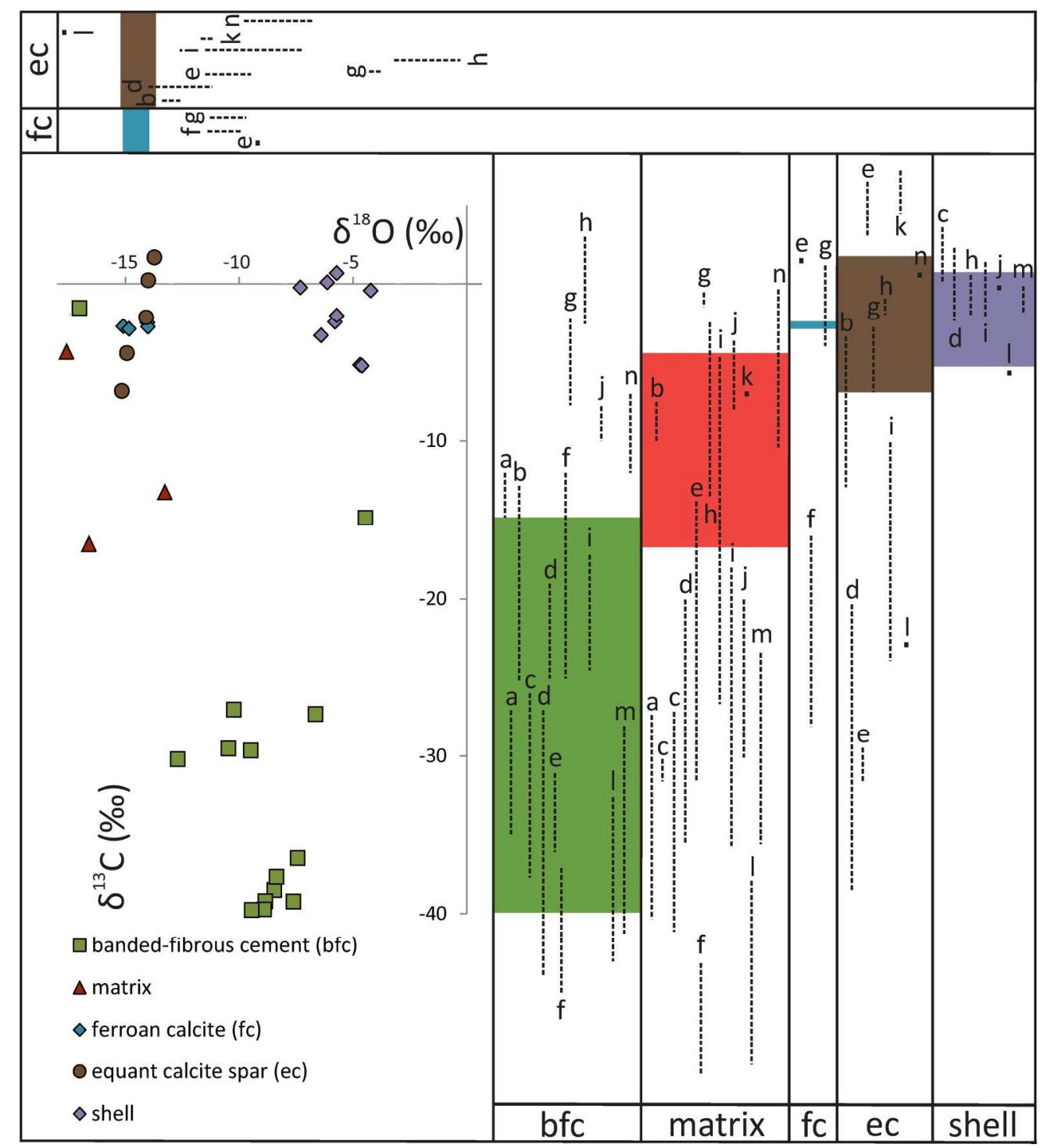

Fig. 11: Cross plot of measured stable isotope ratios and their comparison with published data $193 \times 215 \mathrm{~mm}(300 \times 300 \mathrm{DPI})$ 

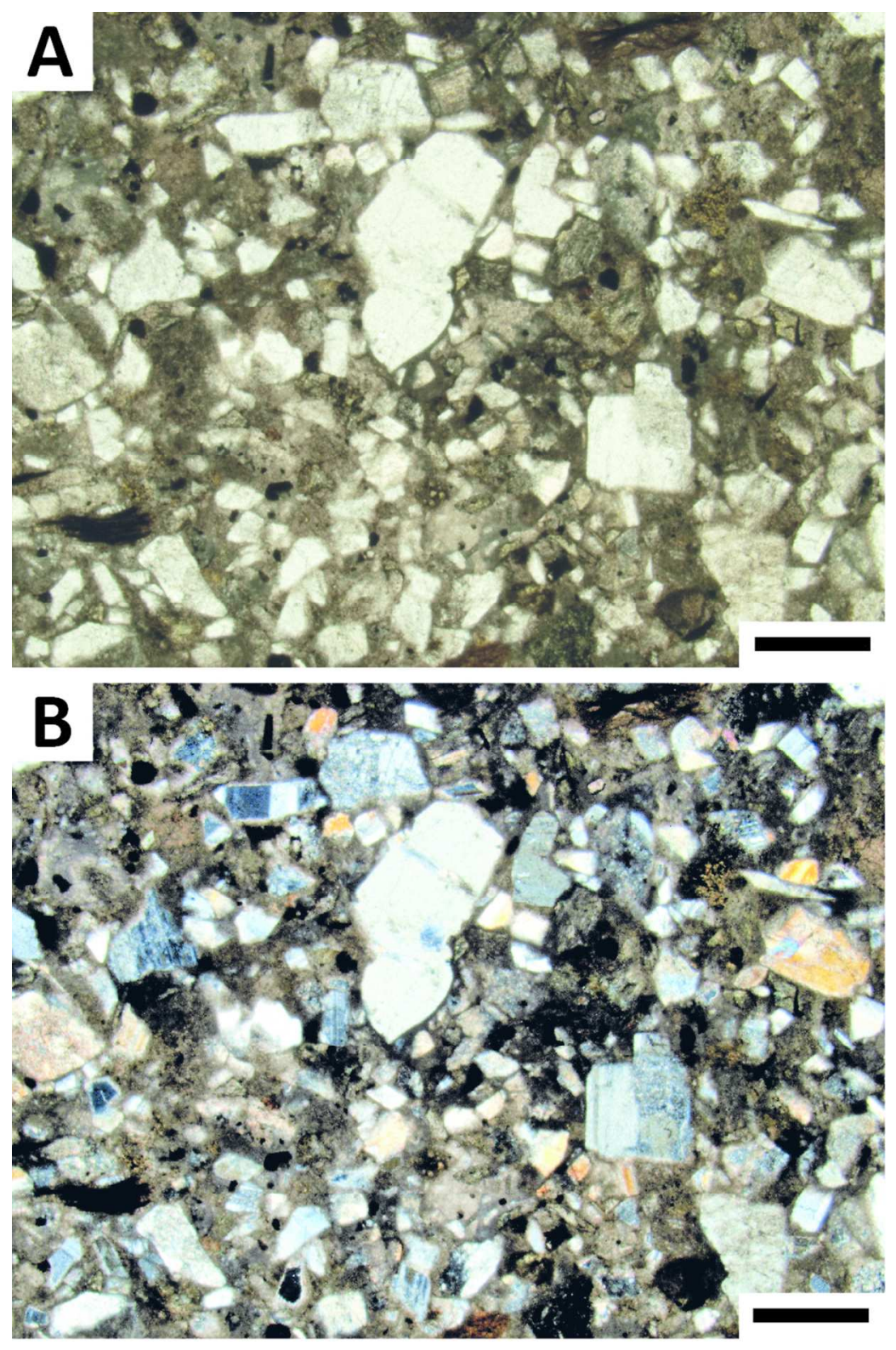

$86 \times 130 \mathrm{~mm}(300 \times 300 \mathrm{DPI})$ 
Table S1. Measurements of all Anarhynchia specimens in this study and figured in published sources.

\begin{tabular}{|c|c|c|c|c|c|c|c|c|c|}
\hline Name & Locality & Specimen No. ${ }^{a}$ & $\begin{array}{l}\text { Length } \\
(\mathbf{m m})^{\mathrm{b}}\end{array}$ & $\begin{array}{l}\text { Width } \\
(\mathbf{m m})^{\mathrm{b}}\end{array}$ & $\mathbf{W} / \mathbf{L}$ & $\begin{array}{l}\text { Thickness } \\
\text { (mm) }\end{array}$ & $\begin{array}{c}\text { Convexity } \\
(2 T h /(L+W))\end{array}$ & $\begin{array}{c}\text { No. of } \\
\text { primary ribs }\end{array}$ & Reference \\
\hline Anarhynchia smithi & Copper Island, Atlin Lake, BC & GSC 139296 & 43 & 53 & 1.23 & 30.5 & 0.64 & 14 & this study \\
\hline Anarhynchia smithi & Copper Island, Atlin Lake, BC & GSC 139299 & 35 & 38 & 1.09 & - & - & 10 & this study \\
\hline Anarhynchia smithi & Copper Island, Atlin Lake, BC & GSC $139297(p t)$ & 52.5 & 54 & 1.03 & - & - & 12 & this study \\
\hline Anarhynchia smithi & Copper Island, Atlin Lake, BC & C-203329/D & 40.3 & - & - & 19 & - & 12 & this study \\
\hline Anarhynchia smithi & Copper Island, Atlin Lake, BC & GSC $139298(\mathrm{pt})$ & 62 & 63 & 1.02 & 34 & 0.54 & 11 & this study \\
\hline Anarhynchia smithi & Copper Island, Atlin Lake, BC & GSC 139300 & 90 & - & - & - & - & 11 & this study \\
\hline Anarhynchia smithi & Copper Island, Atlin Lake, BC & C-203329/I & 28.3 & 31 & 1.10 & - & - & 9 & this study \\
\hline Anarhynchia smithi & Copper Island, Atlin Lake, BC & GSC 139295 (ht) & 28 & 26.5 & 0.95 & 12.5 & 0.46 & 10 & this study \\
\hline Anarhynchia smithi & Copper Island, Atlin Lake, BC & $\mathrm{C}-203329 / \mathrm{K}$ & - & 39 & - & - & - & 9 & this study \\
\hline $\begin{array}{l}\text { Anarhynchia smithi } \\
\text { Anarhynchia smithi }\end{array}$ & $\begin{array}{l}\text { Copper Island, Atlin Lake, BC } \\
\text { Copper Island, Atlin Lake, BC }\end{array}$ & $\begin{array}{l}\text { C-203329/L } \\
\text { GSC 139294 (pt) }\end{array}$ & $\begin{array}{c}39 \\
41.5\end{array}$ & $\begin{array}{c}40 \\
38.5\end{array}$ & $\begin{array}{l}1.03 \\
0.93\end{array}$ & $\begin{array}{c}- \\
23.8\end{array}$ & $\begin{array}{c}- \\
0.60\end{array}$ & $\begin{array}{l}12 \\
18\end{array}$ & $\begin{array}{l}\text { this study } \\
\text { this study }\end{array}$ \\
\hline Anarhynchia gabbi & Bedford Canyon, Santa Ana Mts, CA & J.1223 (ht) & 29.5 & 32 & 1.08 & 14.5 & 0.47 & 15 & Ager 1968 \\
\hline Anarhynchia gabbi & Bedford Canyon, Santa Ana Mts, CA & MS 1684 & 23.1 & 23.5 & 1.02 & 10 & 0.43 & 14 & Sandy 2001 \\
\hline Anarhynchia gabbi & Bedford Canyon, Santa Ana Mts, CA & MS 1685 & 26.2 & 24.6 & 0.94 & 12.3 & 0.48 & 19 & $\begin{array}{l}\text { Sandy } 2001 \\
\text { Sandy } 2001 \text {, }\end{array}$ \\
\hline Anarhynchia gabbi & Bedford Canyon, Santa Ana Mts, CA & MS 1686 & 33.1 & 33.8 & 1.02 & 16.2 & 0.48 & 18 & Little et al. 2004 \\
\hline Anarhynchia gabbi & Bedford Canyon, Santa Ana Mts, CA & MS 1687 & 29.2 & 33.1 & 1.13 & 15.4 & 0.49 & 18 & Sandy 2001 \\
\hline Anarhynchia gabbi & Bedford Canyon, Santa Ana Mts, CA & - & 35.8 & 37.7 & 1.05 & - & - & 17 & Sandy 2010 \\
\hline Anarhynchia gabbi & Bedford Canyon, Santa Ana Mts, CA & - & 26 & 26.9 & 1.03 & - & - & 15 & Sandy 2010 \\
\hline Anarhynchia gabbi & Bedford Canyon, Santa Ana Mts, CA & - & 30 & 27.8 & 0.93 & - & - & 16 & $\begin{array}{l}\text { Sandy } 2010 \\
\text { Little et al. } 1999,\end{array}$ \\
\hline Anarhynchia cf. gabbi & Figueroa, San Rafael Mts, CA & BMNH VF 111 & 18.5 & 16 & 0.86 & - & - & 13 & Little et al. 2004 \\
\hline Anarhynchia cf. gabbi & Figueroa, San Rafael Mts, CA & BMNH VF 113 & 13 & - & - & - & - & 14 & Little et al. 2004 \\
\hline Anarhynchia sp. nov. aff. gabbi & Aldrich Mtn, OR & UCS & 40 & 42 & 1.05 & 15 & 0.37 & 11 & $\begin{array}{l}\text { Manceñido } \\
\text { and Dagys } 1992 \\
\text { Manceñido }\end{array}$ \\
\hline Anarhynchia sp. nov. aff. gabbi & Aldrich Mtn, OR & MLP 24441 & 17.5 & 18 & 1.03 & 8.5 & 0.48 & 10 & and Dagys 1992 \\
\hline Anarhynchia sp. & $4 \mathrm{mi} \mathrm{N}$ of Seneca, OR & B 81622 & 16.25 & 17.5 & 1.08 & 7.5 & 0.44 & 9 & Sandy 2001 \\
\hline Anarhynchia sp. & $4 \mathrm{mi} \mathrm{N}$ of Seneca, OR & B 81621 & 25 & 28.1 & 1.13 & 12.5 & 0.47 & 12 & Sandy 2001 \\
\hline Anarhynchia sp. & $4 \mathrm{mi} \mathrm{N}$ of Seneca, OR & В 81620 & 29.375 & 35.6 & 1.21 & 17.5 & 0.54 & 14 & Sandy 2001 \\
\hline Anarhynchia sp. & Seneca, OR & LSJU & 34.6 & 35.7 & 1.03 & - & & 13 & Sandy 2010 \\
\hline Anarhynchia sp. & Seneca, OR & - & 30.8 & 36.2 & 1.18 & - & - & 12 & Sandy 2010 \\
\hline Anarhynchia(?) sp. & Rio Atuel, Mendoza, Argentina & MLP 24426 & 24 & 24 & 1 & 11 & 0.46 & 13 & $\begin{array}{l}\text { Manceñido } \\
\text { and Dagys } 1992\end{array}$ \\
\hline
\end{tabular}

${ }^{\mathrm{a}} h t$ : holotype, $p t$ : paratype; ${ }^{\mathrm{b}}$ estimated values in italics 
Table S2. Stable isotope data of carbonate phases of Anarhynchia smithi specimens.

\begin{tabular}{|c|c|c|c|}
\hline Sample No. & Component type & $\delta^{13} \mathrm{C}$ & $\delta^{18} \mathrm{O}$ \\
\hline C20B2 & banded-fibrous cement & -38.5 & -8.5 \\
\hline C20C3 & banded-fibrous cement & -30.2 & -12.7 \\
\hline $\mathrm{C} 0 \mathrm{C} 5$ & banded-fibrous cement & -1.5 & -17.0 \\
\hline $\mathrm{C} 0 \mathrm{C} 6$ & banded-fibrous cement & -37.7 & -8.4 \\
\hline $\mathrm{F} 2 \mathrm{H}$ & banded-fibrous cement & -39.2 & -7.6 \\
\hline F3H & banded-fibrous cement & -29.5 & -10.5 \\
\hline F4H & banded inner cement & -39.2 & -8.9 \\
\hline COB6 & banded-fibrous cement & -36.5 & -7.4 \\
\hline COB7.1 & banded-fibrous cement & -39.7 & -8.9 \\
\hline COB7.2 & banded-fibrous cement & -39.8 & -9.5 \\
\hline C20A6 & banded-fibrous cement & -27.3 & -6.6 \\
\hline C20A7 & banded-fibrous cement & -29.6 & -9.5 \\
\hline COA8 & banded-fibrous cement & -14.8 & -4.4 \\
\hline COA9 & banded-fibrous cement & -27.0 & -10.2 \\
\hline C20B5 & matrix & -16.6 & -16.6 \\
\hline COD2 & matrix & -13.2 & -13.3 \\
\hline F1H & matrix & -4.3 & -17.6 \\
\hline COB8 & shell & -3.3 & -6.4 \\
\hline COB9 & shell & -2.4 & -5.8 \\
\hline $\mathrm{C} 20 \mathrm{C} 1$ & shell & -0.4 & -4.2 \\
\hline $\mathrm{C} 20 \mathrm{C} 2$ & shell & -5.2 & -4.7 \\
\hline $\mathrm{C} 0 \mathrm{C} 4$ & shell & 0.1 & -6.1 \\
\hline COD1 & shell & 0.7 & -5.7 \\
\hline COE6 & shell & -0.2 & -7.3 \\
\hline F5H & shell & -5.2 & -4.6 \\
\hline C20B4 & shell (umbo) & -2.0 & -5.7 \\
\hline C20A1 & equant calcite spar & 0.2 & -14.0 \\
\hline $\mathrm{C} 20 \mathrm{~A} 2$ & equant calcite spar & -2.1 & -14.1 \\
\hline COA13 & equant calcite spar & 1.7 & -13.7 \\
\hline COE1 & equant calcite spar & -6.8 & -15.2 \\
\hline COE2 & equant calcite spar & -4.4 & -14.9 \\
\hline COA10 & ferroan calcite & -2.7 & -15.1 \\
\hline COA11 & ferroan calcite & -2.9 & -14.8 \\
\hline COA12.1 & ferroan calcite & -2.5 & -14.0 \\
\hline COA12.2 & ferroan calcite & -2.7 & -14.0 \\
\hline
\end{tabular}


Table S3. Elemental geochemical data of carbonate phases of Anarhynchia smithi specimens.

\begin{tabular}{llcccc}
\hline Sample No. & Component type & $\mathrm{Ca}(\%)$ & $\mathrm{Fe}(\mathrm{ppm})$ & $\mathrm{Mg}(\mathrm{ppm})$ & $\mathrm{Mn}(\mathrm{ppm})$ \\
\hline C20A6 & banded-fibrous cement & 32.9 & 1508 & 7484 & 434 \\
C20B1 & shell & 25.5 & 6953 & 7415 & 1275 \\
C20B2 & banded-fibrous cement & 31.4 & 4214 & 19177 & 839 \\
C20B4 & shell (umbo) & 40.5 & 2079 & 7011 & 1155 \\
C20B5 & matrix & 13.4 & 15559 & 5868 & 1964 \\
C20C1 & shell & 29.1 & 5134 & 8261 & 1017 \\
C20C2 & shell & 19.3 & 4164 & 4481 & 796 \\
C20C3 & banded-fibrous cement & 26.4 & 5169 & 17833 & 809 \\
\hline
\end{tabular}

